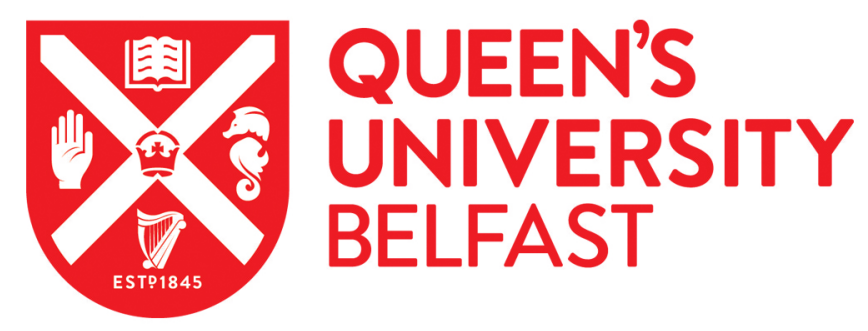

\title{
Export Cartels: Is it Legal to Target your Neighbour? Analysis in Light of Recent Case Law
}

Martyniszyn, M. (2012). Export Cartels: Is it Legal to Target your Neighbour? Analysis in Light of Recent Case Law. JOURNAL OF INTERNATIONAL ECONOMIC LAW, 15(1), 181-222. https://doi.org/10.1093/jiel/jgs003

\author{
Published in: \\ JOURNAL OF INTERNATIONAL ECONOMIC LAW
}

\section{Document Version:}

Peer reviewed version

Queen's University Belfast - Research Portal:

Link to publication record in Queen's University Belfast Research Portal

\section{Publisher rights}

This is a pre-copyedited, author-produced PDF of an article accepted for publication in Journal of International Economic Law following peer review. The version of record Martyniszyn, M. (2012). Export Cartels: Is it Legal to Target your Neighbour? Analysis in Light of Recent Case Law. JOURNAL OF INTERNATIONAL ECONOMIC LAW, 15(1), 181-222. 10.1093/jiel/jgs003 is available online at: http://jiel.oxfordjournals.org/content/15/1/181.

\section{General rights}

Copyright for the publications made accessible via the Queen's University Belfast Research Portal is retained by the author(s) and / or other copyright owners and it is a condition of accessing these publications that users recognise and abide by the legal requirements associated with these rights.

Take down policy

The Research Portal is Queen's institutional repository that provides access to Queen's research output. Every effort has been made to ensure that content in the Research Portal does not infringe any person's rights, or applicable UK laws. If you discover content in the Research Portal that you believe breaches copyright or violates any law, please contact openaccess@qub.ac.uk. 


\title{
Export Cartels: Is it Legal to Target Your Neighbour? Analysis in Light of Recent Case Law
}

\author{
Marek Martyniszyn*
}

\begin{abstract}
Despite the growing sophistication of antitrust regimes around the world, export cartels benefit from special treatment: they are almost universally tolerated, if not encouraged in the countries of origin. Economists do not offer an unambiguous policy recommendation on how to deal with them due in part to the lack of empirical data. This article discusses arguments for and against export cartels and it identifies the existing gaps in the present regulatory framework. The theoretical part is followed by an analysis of the recent case law: a US cartel challenged with different outcomes in India and South Africa, as well as Chinese export cartels pursued in the US. The Chinese cases are particularly topical as the conduct at stake, apart from being subject to private antitrust actions before US courts, was also challenged within the WTO dispute settlement framework, pointing out to the existing interface between trade and competition. While the recent developments prove that unaddressed issues tend not to vanish, the new South-North dimension has the potential of placing export cartels again on the international agenda. Pragmatic thinking suggests looking for the solution within the WTO framework.
\end{abstract}

\section{Disclaimer}

This is a post-print version of the article (not the published version itself). The final, edited version was published in 15(1) Journal of International Economic Law 181 (2012). It is available online at http://jiel.oxfordjournals.org/content/15/1/181.short Please refer to and cite the published version.

\section{Introduction}

Antitrust laws ${ }^{1}$ remain predominantly national. International trade agreements address public restraints of trade and their relevance in the field of competition seems limited. ${ }^{2}$ The international regulatory regime governing competition is a patchwork of rules (different

\footnotetext{
* PhD Candidate, Ad Astra Scholar, University College Dublin School of Law. E-mail: marek.martyniszyn@ucd.ie. Special thanks to Imelda Maher and D. Daniel Sokol who encouraged me to write this article and supported me during the process. Thanks to Morten Hviid, Joseph McMahon, Peter Ormosi, Simon Roberts, Oana Stefan, Andreas Stephan, Spencer Weber Waller, and Yasmeen Yasim who offered their comments on this paper or its parts. The author gratefully acknowledges the comments by the anonymous reviewers of the JIEL. This article was written during a research visit at the Levin College of Law at the University of Florida in summer 2011. I am thankful to my hosts for their kind and generous support. Thanks to the UCD School of Law which co financed this project. The usual disclaimer applies.

${ }^{1}$ The terms antitrust, antitrust laws and competition law are used in this paper interchangeably.

${ }^{2}$ Bilateral or regional trade agreements often include competition law provisions, but frequently such provisions are non-binding. See Anestis S. Papadopoulos, The International Dimension of EU Competition Law and Policy (Cambridge: CUP, 2010) 145-204; D. Daniel Sokol, 'Order without (Enforceable) Law: Why Countries Enter into Non-Enforceable Competition Policy Chapters in Free Trade Agreements', 83 Chicago-Kent Law Review 231 (2008).
} 
national substantive competition rules, different jurisdictional and procedural rules), ${ }^{3}$ coupled with various cooperation agreements ${ }^{4}$ and voluntary cooperation. ${ }^{5}$ Yet business activities are global. ${ }^{6}$

In the last two decades competition authorities around the world invested considerable effort in the fight against transnational anticompetitive conduct focusing particularly on international cartels. This led to some impressive outcomes, such as in case of the vitamin cartel, when it was not only investigated in the US, but thanks to the cooperation between competition authorities it was also successfully challenged, for example, in the EU, Canada,

\footnotetext{
${ }^{3}$ Bhagwati talks about a 'spaghetti bowl' phenomenon in the context of crisscrossing preferential trade agreements, which rules on origin of products distort the incentives to invest purely on the economic efficiency grounds and make the global trading rules non-transparent. On this notion in the context of international trade agreements see Jagdish N. Bhagwati, Termites in the Trading System: How Preferential Agreements Undermine Free Trade (Oxford: OUP, 2008) 61-71. The rules governing the transnational anticompetitive conduct resemble such a spaghetti bowl. See generally Brendan J. Sweeney, The Internationalisation of Competition Rules (London: Routledge, 2010); David J. Gerber, Global Competition: Law, Markets, and Globalization (Oxford OUP, 2010).

${ }^{4}$ For example bilateral cooperation agreements such as between US and, inter alia, Australia, Brazil, Canada, and the EU; for the full list with corresponding texts see http://www.justice.gov/atr/public/international/intarrangements.html (visited 7 January 2012); or the quaternary agreement between Denmark, Iceland, Norway and Sweden, allowing for exchange of confidential information (the agreement was originally tripartite, with Sweden acceding at the later stage), see http://www.norden.org/en/about-nordic-cooperation/agreements/treaties-and-agreements/industry-trade/agreement-between-denmark-iceland-norway-andsweden-concerning-cooperation-in-matters-of-competition (visited 7 January 2012). See generally Bruno Zanettin, Cooperation Between Antitrust Agencies at the International Level (Oxford: Hart Publishing, 2002).

${ }^{5}$ The leading forum of voluntary cooperation in antitrust matters in the International Competition Network (ICN), a virtual network of 114 competition authorities, which also actively involves academics, practitioners and civil society groups. See http://www.internationalcompetitionnetwork.org/ (visited 7 January 2012), compare Andrea Gomes da Silva and Greg Olsen, 'Interview with John Fingleton, Chair of the Steering Group of the International Competition Network (ICN)', 25 Antitrust 71 (2010); Hugh M. Hollman and William E. Kovacic, 'The International Competition Network: Its Past, Current and Future Role', 20 Minnesota Journal of International Law 274 (2011). Apart from ICN, both Organisation for Economic Co-operation and Development (OECD) and United Nations Conference on Trade and Development (UNCTAD) offer a forum for a voluntary cooperation in competition law and policy. These are both intergovernmental bodies: the former offers a perspective of developed economies and it has gained a particular expertise in peer reviews, whereas the latter is characterized by its focus on development and engagement in technical cooperation. See http://www.oecd.org/competition and http://www.unctad.org/Templates/StartPage.asp?intItemID=2068\&lang=1 (visited 7 January 2012). Compare D. Daniel Sokol, 'International Antitrust Institutions', in Andrew T. Guzman (ed), Cooperation, Comity, and Competition Policy (Oxford: OUP, 2011) 194-202.

${ }^{6}$ KOF Index of Globalization and A.T. Kearney/Foreign Policy Globalization Index measure the growing interconnectedness from different perspectives, including its economic aspect. See http://globalization.kof.ethz.ch/ and http://www.atkearney.com/index.php/Publications/globalization-index.html (visited 7 January 2012).
} 
Australia, Korea, Brazil and Mexico. ${ }^{7}$ Despite such developments, little has been done to address the issue of export cartels, ${ }^{8}$ i.e. cartels affecting only foreign markets.

The contribution of this paper is to identify the existing gaps in the present regulatory framework applicable to export cartels, as well as the challenges posed by their operations in the light of the recent case law. The issue of export cartels is being addressed from the competition law perspective, taking into consideration, where appropriate, an international trade dimension.

This paper first summarizes what we know about export cartels, their functions and significance. It then sets outs the views of different states on export cartels, expressed within the World Trade Organization (WTO) framework. This then leads to an analysis of the legal framework applicable to export cartels, with particular regard to extraterritoriality as a unilateral tool available in addressing transnational anticompetitive conduct. The following part looks into recent cases, which point out to various limitations of and challenges faced by the current regulatory regime applicable to export cartels. The conclusions support a call for an international solution to the issue of export cartels in the WTO framework.

\section{Lacking Data and Argumentative Battle}

Export cartels are peculiar creatures: in most competition law regimes, if put into effect domestically, they would be considered illegal, whereas when implemented externally, in foreign jurisdictions, they are considered legal and tolerated (implicitly, as export cartels are simply not covered by domestic competition laws unless they produce domestic effects), if not encouraged, by the very same country of origin. Some consider their operations as "the

\footnotetext{
${ }^{7}$ Harry First, 'Vitamins Case: Cartel Prosecutions and the Coming of International Competition Law', 68 Antitrust Law Journal 711 (2001), at 717-18; John M. Connor, Global Price Fixing, 2nd ed. (Heidelberg: Springer, 2008) 383-91. See also Simon J. Evenett, et al., 'International Cartel Enforcement: Lessons from the 1990s', 24 The World Economy 1221 (2001).

${ }^{8}$ Harding and Joshua define cartel as 'an organization of independent enterprises from the same or similar area of economic activity, formed for the purpose of promoting economic interests by controlling competition between themselves.' Similarly, the OECD Glossary defines cartel as a formal, mutually beneficial agreement among firms in an oligopolistic industry. It also explicitly acknowledges the existence of public cartels, established by government/s. Christopher Harding and Julian Joshua, Regulating Cartels in Europe, 2nd ed. (Oxford: OUP, 2010) 12; OECD, Glossary of Industrial Organisation Economics and Competition Law (1993), 18-19, available at http://www.oecd.org/dataoecd/8/61/2376087.pdf (visited 7 January 2012). Accordingly, export cartels are cartels which focus only on foreign markets, not affecting directly markets in the jurisdictions where cartel members are located. Furthermore, export cartels can be divided into two groups: national export cartels (membership from the single competition law regime) or international export cartels (membership from different regimes).
} 
most obvious sort of anticompetitive beggar-my-neighbour conduct" ${ }^{\text {' }}$ or 'little more than an attempt to enhance domestic welfare at the expense of global welfare or the welfare of consumers in the target market in particular., ${ }^{10}$

Although there is a broad consensus against private international hard core cartels, ${ }^{11}$ this category, as defined in the OECD Recommendation, does not include any type of export cartels. ${ }^{12}$ While, for example, Sweeney distinguishes between international and export cartels, ${ }^{13}$ this article takes a different approach and explicitly recognizes that export cartels may be both national or international in membership (for example Organization of the Petroleum Exporting Countries, OPEC). ${ }^{14}$ In case of the former group it may be argued that they pose little threat: so long as they do not control the world market of a particular good, they should face foreign competition. It may, but does not have to be so, as some national export cartels may have a low world market share, yet a high market share in a particular country or region. ${ }^{15}$ In any case this argument does not apply to international export cartels. Therefore there is no a priori reason why to disregard the issue of export cartels. Furthermore, export cartels do not have to be purely private agreements and there is, similarly, no reason why public, state-run export cartels should escape the scrutiny.

It is acknowledged in the literature that empirical data on export cartels is lacking. ${ }^{16}$ This state of affairs seriously handicaps attempts to analyze this issue. It may well be that the greatest significance of export cartels, as seen through the lens of free trade, is symbolic. The

\footnotetext{
${ }^{9}$ Eleanor M. Fox, 'Competition Law and the Millennium Round', 2 Journal of International Economic Law 665 (1999), at 674.

${ }^{10}$ Florian Becker, 'The Case of Export Cartel Exemptions: Between Competition and Protectionism', 3 Journal of Competition Law and Economics 97 (2007), at 115.

${ }^{11}$ See, for example, Gal calls them 'a primary evil of global trade', extrapolating from the US Supreme Court who called a domestic cartel 'the supreme evil of antitrust'. Verizon Communications v. Law Offices of Curtis V. Trinko, 540 U.S. 398, 408 (2004); Michal S. Gal, 'Free Movement of Judgments: Increasing Deterrence of International Cartels Though Jurisdictional Reliance' (New York University School of Law Law \& Economics Research Paper Series No. 08-44, 2008), 1, available at http://ssrn.com/paper=1291844 (visited 7 January 2012). Compare Margaret C. Levenstein and Valerie Y. Suslow, 'Contemporary International Cartels and Developing Countries: Economic Effects and Implications for Competition Policy', 71 Antitrust Law Journal 801 (2004); OECD, 'Hard Core Cartels Third Report on the Implementation of the 1998 OECD Recommendation', 8 OECD Journal of Competition Law and Policy 7 (2006).

${ }^{12}$ OECD, Recommendation of the Council Concerning Effective Action Against Hard Core Cartels, C(98)35/FINAL (March 1998), para. I(A)2(b), available at http://www.oecd.org/dataoecd/39/4/2350130.pdf (visited 7 January 2012).

${ }^{13}$ Brendan Sweeney, 'Export Cartels: Is there a Need for Global Rules?', 10 Journal of International Economic Law 87 (2007), at 90.

${ }^{14}$ In similar vein Margaret C. Levenstein and Valerie Y. Suslow, 'Changing International Status of Export Cartel Exemptions', 20 American University International Law Review 785 (2005), at 788, n. 6.

${ }^{15}$ See below note 35 and accompanying text.

${ }^{16}$ See, for example, Becker, above n 10, at 116; D. Daniel Sokol, 'What do We Really Know About Export Cartels and What is the Appropriate Solution?', 4 Journal of Competition Law and Economics 967 (2008), at 970-71.
} 
principles underlying trade liberalization have been the antithesis of mercantilism, which is characterized by beggar-thy-neighbour policies. The fact of tolerance or even encouragement of export cartels may be seen, as Sweeney puts it, as a form of neo-mercantilism ${ }^{17}$ and thus contrary to the efforts of trade liberalisation. As the same time, Sokol rightly cautions that due to the lack of empirical data solutions to the issue of export cartels may be too reliant on theory with all the risks connected with the acceptance of various assumptions, which may be misguided. ${ }^{18}$

Arguments in favour of export cartels are various, but not many. The first argument underlines the 'enabling role' of export cartels. It is argued that companies may create export cartels to jointly market products, enter new markets, or achieve sufficient scale to actively participate in world commerce. ${ }^{19}$ It is usually claimed in the context of small and medium size undertakings which, arguably, but for the export cartels would be unable to expand and successfully compete internationally. At the same time it is not clear if such firms actually organize export cartels. ${ }^{20}$ This argument is coupled with an efficiency claim. It is argued that export cartels may lead to efficiency gains, for example by conducting common sales activities, market research, negotiation of shipping rates etc. Those gains, in competitive markets, would lead to more competition in downstream market, which in turn would lead to lower prices. $^{21}$ Therefore such agreements, although lessening competition among their participants, would not act to the detriment of consumers thanks to the efficiency gains.

\footnotetext{
${ }^{17}$ Sweeney, above $\mathrm{n} 13$, at 96.

${ }^{18}$ Sokol, above n 16 , at 971.

${ }^{19}$ Evenett, et al., above n 7, at 1233.

${ }^{20}$ Becker, above n 10, at 116. For example Larson in his study of US Webb-Pomerene export cartels showed that in 1962 (granted a long time ago) 70 per cent of registered export cartels had no members who were small companies (i.e. firms holding assets worth $\$ 1$ million or less). See David A. Larson, 'An Economic Analysis of the Webb-Pomerene Act', 13 Journal of Law and Economics 461 (1970), at 470. Waller, on the other hand, looked at entities registered under the Export Trading Company Act of 1982, which was legislated to further promote US exports and offered registered entities broader immunity than available under the Webb-Pomerene Act. He found that in the first years after its introduction this legislation was availed of almost exclusively by small export intermediaries and by trade associations focusing on a small group of products, markets, or industries. At the same time this program was met with little interest by US businesses and was deemed unsuccessful. As Waller notes there was little in the data suggesting that the ETC Act has caused any fundamental change in the role of small narrowly focused and specialized export intermediaries. See Spencer Weber Waller, 'The Failure of the Export Trading Company Program', 17 North Carolina Journal of International Law and Commercial Regulation 239 (1992), at 250-51; compare Spencer Weber Waller, Antitrust and American Business Abroad, 3rd ed. (St. Paul Minn.: West Group, 1997-2010) ch. 9.

21 Andrew R. Dick, 'Are Export Cartels Efficiency-Enhancing or Monopoly-Promoting' (University of California, Department of Economics Working Paper No. 601, 1990), 2, 13. See also Joel Davidow and Hal Shapiro, 'The Feasibility and Worth of a World Trade Organization Competition Agreement', 37 Journal of World Trade 49 (2003), at 67.
} 
Another rationale is what Becker calls a 'defence argument'. ${ }^{22}$ Export cartels are to facilitate exporting companies' market access to foreign markets which suffer from restricted competition, allowing them to overcome barriers to entry. Exporters may be faced with nontariff barriers, accumulated market power, and other aspects of distorted competition making market access more difficult. Therefore the argument goes as follows: the foreign market is characterized by distorted competition and/ or non-tariff barriers, making it difficult to gain access for foreign companies. In such case creation of an export cartel, coordinating firms' action, allows companies to overcome difficulties (for example to exercise countervailing power against foreign buyers cartels ${ }^{23}$ ), bringing new players to the market, creating more competition, and leading ultimately to increased efficiency. ${ }^{24}$ The issue whether export cartels promote competition in foreign markets as well as access to those markets depends on whether exporters are new entrants or not. If they are new entrants, there is some likelihood that this new entry is the outcome of cooperation. ${ }^{25}$ Export cartels facilitate market penetration in a very distinct set of conditions, i.e. when there are structural impediments to access in the targeted market. In other cases this argument does not apply. ${ }^{26}$

Apart from the anti-cartel arguments valid for all types of cartels and concerning their ability to fix prices at supra-competitive levels or divide markets, ${ }^{27}$ there are some economic arguments that respond directly to the rationale offered in favour of export cartels. They particularly reflect upon the arguably benign effects of export cartels on domestic markets, i.e. domestic markets are not immune from the effect of export cartels. First of all, export cartels whose members have an important part of the domestic market can influence domestic supplies and prices by their export decisions. ${ }^{28}$ In other words, if a significant part of capacity until then engaged in supply of the domestic market is devoted to supply the export markets, the domestic output and prices will be affected. But it seems that the most important argument against the tolerance of export cartels, from the perspective of their home state, is

\footnotetext{
${ }^{22}$ Becker, above n 10, at 116.

${ }^{23}$ James D. Whitney, 'The Causes and Consequences of Webb-Pomerene Associations: A Reappraisal', 38 Antitrust Bulletin 395 (1993), at 398.

${ }^{24}$ Compare Becker, above n 10, at 116.

${ }^{25}$ In this vein ibid, at 117; Aditya Bhattacharjea, 'Export Cartels-A Developing Country Perspective', 38 Journal of World Trade 331 (2004), at 350.

${ }^{26}$ Becker, above n 10, at 118 .

${ }^{27}$ See generally Loius Kaplow and Carl Shapiro, 'Antitrust', in A. Mitchell Polinsky and Steven Shavell (eds), Handbook of Law and Economics (Amsterdam: Elsevier, 2007) Vol. 2; Alexis Jacquemin and Margaet E. Slade, 'Cartels, Collusion, and Horizontal Merger', in Richard Schmalensee and Robert D. Willig (eds), Handbook of Industrial Organization (Amsterdam: North-Holland, 1989) Vol 1; George J. Stigler, 'A Theory of Oligopoly', 72 The Journal of Political Economy 44 (1964).

${ }^{28}$ Ulrich Immenga, 'Export Cartels and Voluntary Export Restraints between Trade and Competition Policy', 4 Pacific Rim Law \& Policy Journal 93 (1995), at 125-26.
} 
that there is a threat of expansion of export cartel operations to the domestic market. ${ }^{29}$ Their successful cooperation in foreign markets incentivizes companies to follow the same strategy at home. The fact of cooperation abroad, involving exchange of information concerning prices, costs, or other polices, leads to increased visibility between firms and it is likely to influence the domestic conduct of firms. Even if they do not organize a cartel on the domestic market, there is a possibility of conscious parallelism, ${ }^{30}$ otherwise known as tacit collusion. Without any explicit agreement with regard to their operation on the domestic market, firms having sufficient knowledge about each other, thanks to participation in export cartel, may behave in a similar way, as if there was a domestic cartel, ${ }^{31}$ and while subject to national competition laws successfully enforcing those laws against tacit collusions is very difficult.

Bhattacharjea notes that when assessing the impact of an export cartel at the end of the day 'it all depends', and that a number of issues needs to be considered in each particular case, among them: ${ }^{32}$ (1) is the cartel a new entrant, (2) the nature of efficiencies claimed, (3) the market structure, (4) the degree of import penetration. Dick, ${ }^{33}$ while analysing the operations of US registered export cartels provides a useful general framework, distinguishing monopoly-promoting and efficiency-enhancing export cartels. He notes that the monopoly hypothesis (export cartels exercise market power, raise prices and lead to reduced exports, as firms export less in a cartel than when acting competitively ${ }^{34}$ ) is more plausible when cartels have a large share of the world market and face relatively disorganized buyers. At the same time, some export cartels while internationally not influential may have a significant share of particular markets. This can be an issue in case of former colonies, due to survival of trade patterns shaped in the past. ${ }^{35}$ The less competition a cartel faces in the targeted country, the greater its opportunity to exercise market power. In effect, the countries with less developed industries are more likely to suffer harm, than developed economies with

\footnotetext{
${ }^{29}$ Becker, above n 10, at 119. Schultz shows that export cartels may lead to anticompetitive effects on domestic market, at least when markets are not too different or in case of constant returns to scale. See Christian Schultz, 'Export Cartels and Domestic Markets', 2 Journal of Industry, Competition and Trade 233 (2002).

${ }^{30}$ OECD, Export Cartels. Report of the Committee of Experts on Restrictive Business Practices (Paris: OECD, 1974) 50.

${ }^{31}$ Compare OECD, above n 8, at 26-27; Reza Dibadj, 'Conscious Parallelism Revisited', 47 San Diego Law Review 589 (2010).

${ }^{32}$ Bhattacharjea, above $\mathrm{n} 25$, at 354 .

${ }^{33}$ See generally Dick, above n $21,2-3$.

${ }^{34}$ Interestingly it seems that the hypothesis on reduced volumes of export is reflected in Canadian export cartels exemption, which does not apply if such a cartel 'has resulted in or is likely to result in a reduction or limitation of the real value of exports of a product', yet Canadian law does not require registration of export cartels. Competition Act, R.S.C., 1985, c. C-34, as amended, para. 45(5)(a).

${ }^{35}$ Bhattacharjea, above n 25, at 348. See also James E. Rauch, 'Networks Versus Markets in International Trade', 48 Journal of International Economics 7 (1999).
} 
competitive markets. ${ }^{36}$ Export cartels have greater incentives to enter non-competitive markets where there is greater scope for higher prices. The efficiency defence (export cartel lead to efficiency gains which are passed on to consumers via lower prices) is most likely when firms incur large fixed costs to operate abroad and their market share is relatively small. ${ }^{37}$

The foregoing arguments for and against export cartels show that an unambiguous policy recommendation on how to handle them and a consensus among experts are lacking. Export cartels may or may not cause severe harm however the empirical data in that regard is missing and there is no reason to believe it may be collected, taking into consideration their predominantly secret character. ${ }^{38}$ At the same time there are valid arguments showing that in certain circumstances export cartels may be beneficial to consumers. As well as analysing export cartels from a law and economic perspective, regard also has to be had to institutional assessment in relation to national competition authorities' capacity (legal instruments, expertise, budgets). While a case-by-case analysis of export cartels may be a favourable approach due to the unsettled economic stance, any proposed solution should take into account the actual capacity constraints of competition authorities in many developing and least-developed countries, which may not be able to evaluate individual cases or monitor the domestic effects of home-based export cartels.

\section{Discussion in the WTO Framework ${ }^{39}$}

In 1996 a WTO Working Group on the Interaction between Trade and Competition Policy has been set up to consider issues on the interface of trade and competition as part of

\footnotetext{
${ }^{36}$ Immenga, above n 28, at 126.

${ }^{37}$ Dick, above n $21,11$.

${ }^{38}$ The word 'secret' reflects the fact that even when domestically legal, export cartels have no incentive to mark their presence, as they could be subject to legal action in targeted jurisdictions. They are 'predominantly' secret, because some regimes grant their export cartels exemptions from the scope of national competition laws only after their notification/registration and require reporting. That is the case, for example, in the US under both the Webb-Pomerene Act of 1918 and the Export Trading Company Act of 1982; and in Australia under the Trade Practices Act of 1974, but unlike the US, where the information about the granted exemptions is published, the Australian competition authority is not permitted to disclose information about applications). Levenstein and Suslow, who analyzed export cartel exemptions in 55 regimes, marked a trend to elimination of explicit exemptions, noting the elimination of reporting requirements reduces the information available about export cartels. Levenstein and Suslow, above n 14, at 806-15.

${ }^{39}$ It is worth pointing out that the International Competition Network (ICN) runs a 'Cartel Group', but the issue of export cartels has not been, until now, the focus of its attention. The documents of the ICN Cartel Group are available online at

http://www.internationalcompetitionnetwork.org/library.aspx? search=\&group=2\&type=0\&workshop=0 (visited 7 January 2012).
} 
discussions as to whether or not to include competition within the framework of the WTO. ${ }^{40}$ Export cartels were discussed on a number of occasions, yet consensus was neither found on the issue of their significance, nor on a future regulatory approach.

There was no common position among industrialized states. The EU (the European Community at that time ${ }^{41}$ ) explicitly considered export cartels as having distortionary effects on trade as well as a harmful impact on development. ${ }^{42}$ Japan recognized that export cartels distort trade and opted for their regulation, or even prohibition, within the WTO framework. ${ }^{43}$ The US, who expressly allows export cartels, defended them recognizing an enabling and efficiency arguments. It pointed to the OECD Recommendation ${ }^{44}$ permitting members to exclude export cartels from cartel enforcement in a transparent manner ${ }^{45}$ and suggested exclusion from a definition of hardcore cartels for agreements having 'a significant potential to enhance efficiency'. They underlined that export cartels may have procompetitive effects, allowing firms that hitherto did not engage in export activities to do so. ${ }^{46}$ Moreover, the US claimed that export cartels may bring innovation and lower prices, underlining that their prohibition or per se treatment would be inappropriate. ${ }^{47}$

For developing countries, the clearest position on this issue was taken by Thailand, which called for abolition of export cartel exemptions in industrialized states. It considered

\footnotetext{
${ }^{40}$ The group has been set up as a result of the WTO Ministerial Conference in Singapore in 1996 'to study issues raised by Members relating to the interaction between trade and competition policy, including anticompetitive practices, in order to identify any areas that may merit further consideration in the WTO framework'. Singapore Ministerial Declaration, WT/MIN(96)/DEC (13 December 1996), para. 20, available at http://www.wto.org/english/thewto_e/minist_e/min96_e/wtodec_e.htm (visited 7 January 2012). It was active until mid-2003. For more on the history of the Working Group see http://www.wto.org/english/tratop_e/comp_e/history_e.htm (visited 7 January 2012).

${ }^{41}$ The European Economic Community, established by the Treaty of Rome in 1957, was renamed by the Treaty on the European Union (Treaty of Maastricht), in 1993, as the European Community. The European Union was established as an overarching framework over the European Community, the European Coal and Steel Community and the Euratom, yet it itself lacked legal personality and it was the European Community who had the capacity to enter into international agreements. The recent Lisbon Treaty, amending the Treaties of Maastricht and Rome (the latter was also renamed to Treaty on the Functioning of the European Union, TFEU), which entered into force in December 2009, changed this situation and the legal personality was explicitly granted to the European Union, which replaced and succeeded the Community. See Alina Kaczorowska, European Union Law, 2nd ed. (London: Routledge-Cavendish, 2010) 1-38. Furthermore, in accordance with Art. 207 of the TFEU the trade policy is the competence of the EU and the European Commission representative speaks on the WTO forum on behalf of the EU, which is itself also a member of the WTO, and its member states. Compare http://ec.europa.eu/trade/creating-opportunities/eu-and-wto/working-with-the-wto/ (visited 7 January 2012).

${ }^{42}$ Report of the Meeting of 2-3 October 2000, WT/WGTCP/M/12 (8 November 2000), para. 67.

${ }^{43}$ Communication from Japan, WT/WGTCP/W/156 (19 December 2000), para. 4.

${ }^{44}$ OECD, above $\mathrm{n} 12$.

${ }^{45}$ Communication from the United States, WT/WGTCP/W/203 (15 August 2002), paras 7-8.

${ }^{46}$ Report on the Meeting of 1-2 July 2002, WT/WGTCP/M/18 (20 September 2002), para. 44.

${ }^{47}$ Report on the Meeting of 20-21 February 2003, WT/WGTCP/M/21 (26 May 2003), para. 37.
} 
'the use of export cartels as a strategic trade policy to extract "rents" from foreign countries is unacceptable'. ${ }^{48}$ Furthermore, it recognized export cartels as 'potentially damaging' to developing countries' economies, in terms of worsening their terms of trade. ${ }^{49}$ At the same time as an expression of special and differential treatment, ${ }^{50}$ Thailand argued that developing countries should be allowed to exempt domestic and international export cartels. The suggested rationale was the need to allow 'mainly small scale' importers and exporters in those countries to gain countervailing power against buyers or sellers from developed countries. ${ }^{51}$ The Thai proposal was supported by Indonesia ${ }^{52}$ and China. The latter also recognized that maintenance of export cartels exemptions in the competition laws of developed states would further disadvantage developing countries. ${ }^{53}$ In a similar way, UNCTAD suggested that developed countries should abolish export cartels exemptions on a non-reciprocal basis. ${ }^{54}$ Later the Thai position somewhat softened, calling for at least a caseby-case approach instead of a prohibition. ${ }^{55}$ It is noteworthy that Brazil cautioned about export cartels exemptions, which it considered 'tantamount to a licence to hurt other economies', especially developing countries, without calling for special exception for the latter group. ${ }^{56}$

The developing countries were reluctant in opt in to an agreement on competition, afraid of high compliance costs and little actual benefits. ${ }^{57}$ In fact a few days before the Cancun Ministerial Conference in 2003, in a common submission they opposed the lack of consideration of their views on competition and other so-called Singapore issues ${ }^{58}$ in the draft

\footnotetext{
${ }^{48}$ Communication from Thailand, WT/WGTCP/W/213/Rev.1 (26 September 2002), para. 2.1.

${ }^{49}$ Ibid.

50 The special and differential treatment (SDT) is a WTO term describing special right granted developing countries, for example preferential market access, greater freedom to use trade policies otherwise prohibited, limited reciprocity in trade negotiations, transition periods with regard to implementation of some obligations. For more on SDT see Bernard Hoekman, 'Operationalizing the Concept of Policy Space in the WTO: Beyond Special and Differential Treatment', 8 Journal of International Economic Law 405 (2005); Sheila Page and Peter Kleen, 'Special and Differential Treatment of Developing Countries in the World Trade Organization', Swedish Ministry for Foreign Affairs Global Development Studies 2 (2005), available at http://www.odi.org.uk/resources/details.asp?id=2445\&title=special-differential-treatment-developing-countriesworld-trade-organization (visited 7 January 2012).

${ }^{51}$ Communication from Thailand, above $\mathrm{n} 48$, para. 5.

${ }^{52}$ Report on the Meeting of 26-27 September 2002, WT/WGTCP/M/19 (15 November 2002), para. 53.

${ }^{53}$ Communication from China, WT/WGTCP/W/241 (25 July 2003), para. 6.

${ }^{54}$ Communication from UNCTAD, WT/WGTCP/W/197 (15 August 2002), paras 50, 53, 72.

${ }^{55}$ Report on the Meeting of 20-21 February 2003, above $\mathrm{n} 47$, at para 44.

${ }^{56}$ Report on the Meeting of 26-27 May 2003, WT/WGTCP/M/22 (9 July 2003), para. 111.

${ }^{57}$ In this vein Aditya Bhattacharjea, 'The Case for a Multilateral Agreement on Competition Policy: A Developing Country Perspective', 9 Journal of International Economic Law 293 (2006), at 297.

58 At the 1996 Ministerial Conference in Singapore the WTO members decided to set up three working groups on trade and competition, trade and investment, and on transparency in government procurement. They also instructed the WTO General Council, the highest decision making body of the WTO, to look into the possible
} 
of the Ministerial Declaration. They raised key questions, among them: whether the definition of hardcore cartels will include export cartels, what would be the scope of exemptions from the general prohibition of the former, and whether intergovernmental arrangements are to fall under the definition of hardcore cartels. ${ }^{59}$ The deadlock of negotiations during the Cancun Ministerial Conference led to the negotiation of the so-called 'July 2004 package'. In this framework the WTO General Council decided that the issue of competition policy 'will not form part of the Work Programme set out in that Declaration and therefore no work towards negotiations on any of these issues will take place within the WTO during the Doha Round, ${ }^{60}$ and the Working Group became inactive.

\section{Present Legal Framework}

Virtually all jurisdictions permit export cartels, ${ }^{61}$ either explicitly, requiring prior notification and/ or registration, or implicitly, by limiting cartels prohibition to those affecting domestic markets only. If the care for national welfare is the objective of national competition laws, then, at least in the short turn, ${ }^{62}$ export cartels positively contribute to the national economy, as they extract surplus from foreign consumers and transfer it into the profits of home based companies. ${ }^{63}$ Some of the explicit exemptions are motivated by mercantilism, a willingness to give national companies an extra competitive advantage. ${ }^{64}$ Hoekman and Saggi claim that it is the 'sole purpose' of the still legal status of export cartels. ${ }^{65}$

The means by which export cartels remain legal in the state of origin matter. The more common implicit exemption deprives the home state of the possibility to monitor

\footnotetext{
ways of simplifying trade procedures, so-called trade facilitation. These four issues were later referred to as the Singapore issues. For broader discussion see Simon J. Evenett, 'Five Hypotheses Concerning the Fate of the Singapore Issues in the Doha Round', 23 Oxford Review of Economic Policy 392 (2007).

59 Communication from Bangladesh (on behalf of the LDC Group), Botswana, China, Cuba, Egypt, India, Indonesia, Kenya, Malaysia, Nigeria, Philippines, Tanzania, Uganda, Venezuela, Zambia and Zimbabwe, WT/MIN(3)/W/4 (4 September 2003), 2nd Annex, para. 3.

${ }^{60}$ Decision Adopted by the General Council on 1 August 2004, WT/L/579 (2 August 2004), para. 1(g). See also Josef Drexl, 'International Competition Policy after Cancun', 27 World Competition 419 (2006).

${ }^{61}$ Levenstein and Suslow who examined status of export cartels exemptions in fifty five jurisdictions, found no such exemption in four of them (Luxembourg, Russia, Thailand and Uruguay). Compare Levenstein and Suslow, above n 14, at 819-20. Fried reporting on this issue to the Inter-American Juridical Committee of the Organization of American States was unable to identify any jurisdiction prohibiting them. See Jonathan Fried, Cartels and Competition Law in the Americas: Hard Core and Export Cartels, CJI/doc.102/02 (2002), 90, available at http://www.oas.org/cji/eng/infoanual.cji.2002.ing.pdf (visited 7 January 2012).

${ }^{62}$ Fox and Odrover note that beyond the short run their operations may lead to various retaliatory measures.

${ }^{63}$ Eleanor M. Fox and Janusz A. Ordover, 'The Harmonization of Competition and Trade Law: the Case for Modest Linkages of Law and Limits to Parochial State Action', 19 World Competition 5 (1995), at 14-15.

${ }^{64}$ Evenett, et al., above n 7, at 1230 .

${ }^{65}$ Bernard Hoekman and Kamal Saggi, 'Tariff Bindings and Bilateral Cooperation on Export Cartels', 83 Journal of Development Economics 141 (2007), at 142.
} 
possible efficiency gains, and makes it difficult to scrutinize any spillover effects on the domestic market. ${ }^{66}$ At the same time, the lack of any registration requirement in the state of origin makes it more difficult for export cartels' competitors or even competition authorities in targeted states to discover cartel operations. In this sense, explicit exemptions and registration requirements provide some transparency. They allow competitors or targeted states to react if needed. Also national competition authorities benefit from the possibility of oversight to make sure that the companies engaged in an export cartel do not try to act in an anticompetitive way domestically, or that their activities do not have spillover effects on domestic markets. ${ }^{67}$

Until now the international community has not developed international rules or mechanisms addressing cartels, including export cartels. ${ }^{68}$ There is no international forum authorized to work towards a legally binding compromise or common rules in this regard. The WTO is without a mandate to deal with such issues, although in cases of state-related export cartels there is a possibility of triggering the WTO dispute settlement framework in at least three circumstances. First, Article XI of the General Agreement on Tariffs and Trade $(\mathrm{GATT})^{69}$ prohibits WTO members imposing or maintaining import and export restrictions. The Panel report in Japan-Trade in Semi-Conductors, ${ }^{70}$ where it has been established that a governmental scheme restricting the exportation of goods below certain price falls under prohibition of Article XI:1. ${ }^{71}$ By corollary a state-endorsed export cartel where the parties

\footnotetext{
${ }^{66}$ Becker, above n 10, at 118.

${ }^{67}$ Ibid, at 113 .

${ }^{68}$ Although there are some international soft-law instruments, see, for example, OECD; UNCTAD, Model Law on Competition. Substantive Possible Elements for a Competition Law, Commentaries and Alternative Approaches in Existing Legislations, TD/RBP/CONF.5/7/Rev.3 (2007). Note: the OECD Recommendation allows to exempt export cartels from the scope of prohibition.

${ }^{69}$ WTO, The Legal Texts: the Results of the Uruguay Round of Multilateral Trade Negotiations (Cambridge: CUP, 1999) 423.

${ }^{70}$ GATT Panel Report, Japan - Trade in Semi-Conductors, L/6309, adopted 4 May 1988, BISD 35S/116.

${ }^{71}$ The case concerned an agreement between the US and Japan, in which Japan, in order to avoid antidumping investigation, agreed inter alia, to monitor export prices of semiconductors to the US, so as to restrict the exports below certain price. The panel found that although the monitoring procedure was only a non-binding administrative guidance, it discouraged exporters to sell at lower prices, and could be considered a 'governmental measure' within the meaning of Article XI:1, if (1) 'reasonable grounds exist to believe that the sufficient incentives or disincentive existed for non-mandatory measures to take effect', and (2) 'the operation of the measures to restrict export of semi-conductors at prices below company-specific costs was essentially dependent on Government action or intervention'. Ibid, at para. 109. Compare Merit E. Janow, 'What Role for Competition Policy in the WTO?' (2002), available at http://www.columbia.edu/ mj60/PDF/janow\%20rorcam\%20912.pdf (visited 7 January 2012); Claus-Dieter Ehlermann and Lothar Ehring, 'WTO Dispute Settlement and Competition Law: Views from the Perspective of the Appellate Body's Experience', 26 Fordham International Law Journal 1505 (2003). The Article VI of GATT and the Anti-Dumping Agreement form the WTO antidumping regime, which allows states affected by dumping, within the meaning of these provisions, to impose antidumping duties. The Article 18.1 of the AntiDumping Agreements clarifies that no other action may be taken against dumping, apart from imposition of
} 
agree prices may fall within Article XI:1. In China-Measures Related to the Exportation of Various Raw Materials Panel adopted such an approach. ${ }^{72}$ Second, Article 11.1(b) of the Agreement on Safeguards ${ }^{73}$ prohibits ordering, or encouraging voluntary export restraints. Export cartels with state involvement could fall into this category as well. Finally, within the WTO framework it is possible to bring a so-called non-violation complaint, ${ }^{74}$ alleging that some new laws or regulations introduced in a particular WTO member state (in this case organizing or sanctioning export cartels) nullify or impair the benefits of WTO membership. ${ }^{75}$

Therefore, in principle, a government organizing or compelling export cartels might be found in breach of its WTO obligations. ${ }^{76}$ Yet, even if these provisions prove capable of addressing state involvement in export cartels, they do not address the issue of private export cartels.

From the perspective of a targeted state, the only way to handle export cartels formally is to act unilaterally and apply national competition laws extraterritorially. ${ }^{77}$ Extraterritoriality seems to be a phenomenon of particular relevance in antitrust. It gradually

antidumping duties. Agreement on the Implementation of Art. VI GATT (Anti-Dumping Agreement). WTO, at 147. This issue was at stake in the Act of 1916 case, where the old US antitrust provision, providing for criminal prosecution and treble damages in certain cases of dumping, was successfully challenged (leading to its repeal) by the EU (then the EC) and Japan in the WTO. The Appellate Body, confirming the Panel finding of the US violation, noted that '(d)umping is always transnational price discrimination, but transnational price discrimination is not always dumping', pointing out to the interplay and possible overlap between antitrust and international trade regime. See WTO Appellate Body Report, United States - Anti-Dumping Act of 1916, WT/DS136/AB/R, WT/DS162/AB/R, adopted 26 September 2000, DSR 2000:X, 4793, para. 133, n. 71. Compare Mitsuo Matsushita, 'Basic Principles of the WTO and the Role of Competition Policy', 3 Washington University Global Studies Law Review 363 (2004), at 371-73.

${ }^{72}$ WTO Panel Report, China- Measures Related to the Exportation of Various Raw Materials, WT/DS394/R, WT/DS395/R, WT/DS398/R, adopted 5 July 2011. For more on this case see below text accompanying notes 192-201. Note that on appeal the Appellate Body, on procedural grounds, found the Panel findings moot and of no legal effects. See below text accompanying notes 202-205.

${ }^{73}$ WTO, above n 69, at 275.

${ }^{74}$ Art. XXIII:1(b) GATT, Art. XXIII General Agreement on Trade in Services (GATS). Ibid, at 286.

75 Matsushita, then the Member of the WTO Appellate Body, in a similar vein on this three possibilities of challenging state-related export cartels in the WTO, see Mitsuo Matsushita, 'The Intersection of Industrial Policy and Competition: The Japanese Experience', 72 Chicago-Kent Law Review 477 (1996), at 498-500. For the skeptical view with regard to the reliance on non-violation complaint see Chris Noonan, The Emerging Principles of International Competition Law (Oxford: OUP, 2008) 430-32.

${ }^{76}$ Noonan, above n 75, at 418-20; Bernard Hoekman and Petros C. Mavroidis, 'Economic Development, Competition Policy and the World Trade Organization', 37 Journal of World Trade 1 (2003), at 13.

77 See generally Menno T. Kamminga, 'Extraterritoriality', in Rüdiger Wolfrum (ed), The Max Planck Encyclopedia of Public International Law, online ed. (OUP, 2010). In the context of antitrust see Eleanor M. Fox, 'Can we Solve the Antitrust Problems of Globalization by Extraterritoriality and Cooperation? Sufficiency and Legitimacy', 48 Antitrust Bulletin 355 (2003); Damien Geradin, et al., 'Extraterritoriality, Comity and Cooperation in EC Competition Law' (SSRN eLibrary 2008), available at http://ssrn.com/abstract=1175003 (visited 7 January 2012); Brendan Sweeney, 'Combating Foreign Anti-competitive Conduct: What Role for Extraterritorialism?', 8 Melbourne Journal of International Law 35 (2007). 
earned its present practical paramount importance with the development of the effects doctrine. This jurisdictional theory, introduced first in the US in $1945,{ }^{78}$ provides for prescriptive jurisdiction ${ }^{79}$ over foreign-based persons and their foreign conduct if economic effects are experienced on the domestic market. It is a valuable tool in the fight against foreign anticompetitive arrangements in the absence of any international framework. The acceptance of the effects doctrine as a jurisdictional basis has been a long process, with the international community and scholars being split as to its legality and normative force. ${ }^{80}$ Nevertheless, various forms of effects doctrine have been introduced through legislation or jurisprudence in many jurisdictions,${ }^{81}$ providing for its present broad recognition.

\footnotetext{
${ }^{78}$ United States v. Aluminium Company of America (Alcoa), 148 F.2d 416 (2nd Cir. 1945).

${ }^{79}$ The term 'jurisdiction' has various meanings under international law. In this context the Restatement in Section 401 distinguishes between prescriptive, adjudicative and enforcement jurisdiction. It defines jurisdiction to prescribe as a capacity 'to make its law applicable to the activities, relations, or status of persons, or the interests of persons in things, whether by legislation, by executive act or order, by administrative rule or regulation, or by determination of a court. American Law Institute, Restatement of the Law (Thrid): Foreign Relations Law of the United States (St. Paul, Minn.: American Law Institute Publishers, 1987). Compare Michael Akehurst, 'Jurisdiction in International Law', 46 British Yearbook of International Law 145 (1973), at 326-28; Andreas F. Lowenfeld, 'Public Law in the International Arena: Conflict of Laws, International Law and Some Suggestions for Their Interaction', 163 Recueil des Cours 311 (1979), at 326-28.

${ }^{80}$ Recently the Group of 77 and China protested against extraterritoriality, by expressing: 'their deep concern at the increased application of coercive economic measures and unilateral sanctions against developing countries, including the new attempts aimed at extraterritorial application of domestic law, despite the rejection by the vast majority of the international community and the adoption of several resolutions by the United Nations General Assembly that urged the adoption of urgent and effective measures to eliminate them.' UNCTAD, Communication from the Group of 77 and China Regarding the Application of Coercive Economic Measures and Unilateral Sanctions Against Developing Countries, TD/411 (2004), available at http://www.unctad.org/en/docs/td411_en.pdf (visited 7 January 2012). Group of 77 is an intergovernmental organization established by seventy seven developing states in 1964, as of January 2012 it comprises 132 states. It usually acts and takes positions together with China. See http://www.g77.org/ (visited 7 January 2012). Van Gerven commenting on the implementation doctrine (the EU jurisdictional basis for extraterritoriality analogous to the US effects doctrine, but more limited in its reach; triggered by a sale within the EU, irrespective of the location of a firm) noted that '[a sale] does not constitute a sufficiently close and relevant link with the regulating State that is compelling enough to justify jurisdiction on its part.' Walter van Gerven, 'EC Jurisdiction in Antitrust Matters: The Wood Pulp Judgment', Fordham Corporate Law Institute 451 (1989), at 470. Compare D. Geradin, et al., 'Extraterritoriality, Comity and Cooperation in EC Competition Law', in Andrew T. Guzman (ed), Cooperation, Comity, and Competition Policy (Oxford: OUP, 2011).

${ }^{81}$ Art. 2(2) of the Chinese competition law makes the law applicable 'to the conducts outside the territory of the People's Republic of China if they eliminate or have restrictive effect on competition on the domestic market of the PRC.' Anti-Monopoly Law of the People's Republic of China (2007), available at http://www.china.org.cn/government/laws/2009-02/10/content_17254169.htm (visited 7 January 2012). Similarly, Art. 2 of Brazilian antitrust law makes the law applicable 'to acts wholly or partially performed within the Brazilian territory, or the effects of which are or may be suffered therein.' Law 8884, Official Gazette of the Federal Executive of June 13 (1994), available at http://www.cade.gov.br/english/internacional/Law8884-1994b.pdf (visited 7 January 2012). In Australia the 2009 amendment to the competition law extended the reach of the Act to agreements containing a provision which 'have the purpose, or has or is likely to have the effect, of directly or indirectly' lessening competition, making it applicable to foreign parties with no presence or business activities in Australia. Competition and Consumer Act 2010, Act No. 51 of 1974 as amended, compare Jackie Mortensen, 'Extending the Extraterritorial Reach of the Trade Practices Act', 614 Australian Trade Practices News 1 (2009).
} 
Extraterritoriality is potentially a powerful instrument, yet it suffers from various limitations and may not be, for practical reasons, available to all states. This is particularly so in case of developing and least-developed states. Even if they are in principle equipped with competition laws, and this is not always the case, ${ }^{82}$ such laws need to be coupled with necessary capacity and resources to be effectively enforced. ${ }^{83}$ Even if the preconditions are fulfilled, in transnational cases the evidence lies most likely abroad. ${ }^{84}$ Assuming that evidence is not an issue (a very theoretical assumption), there may be simply no scope for enforcement. Laws may prove in such cases toothless, as the assets of the parties involved may be based abroad, and as markets of such states often matter little, investment- and saleswise, the fined companies may decide to abandon the market instead of paying the penalties or damages. Backer calls it an enforcement asymmetry. ${ }^{85}$ Fox talks about "practical disenfranchisement of victim jurisdictions that lack resources and are vulnerable'. ${ }^{86}$ Hawk uses the phrase 'enforcement lacuna'. ${ }^{87}$ This issue concerns not only developing countries, but also, for example, small and remote jurisdictions, ${ }^{88}$ which may lack the commercial importance or political power necessary to make extraterritoriality work in practice. ${ }^{89}$

\footnotetext{
${ }^{82}$ More than a hundred states adopted competition laws. International Bar Association Global Competition Forum provides an online database of competition laws around the world (listing also states without such provisions). See http://www.globalcompetitionforum.org/ (visited 7 January 2012).

${ }^{83}$ The practical value of having a competition regime and the challenges faced in its operation from the perspective of developing countries are analyzed by Jenny: Frederic Jenny, 'Cartels and Collusion in Developing Countries Lessons from Empirical Evidence', 29 World Competition 109 (2006). Compare Maher M. Dabbah, 'Competition Law and Policy in Developing Countries: A Critical Assessment of the Challenges to Establishing an Effective Competition Law Regime', 33 World Competition 457 (2010); Eleanor M. Fox, 'Economic Development, Poverty, and Antitrust: The Other Path', 13 Southwestern Journal of Law and Trade in the Americas 211 (2007). For more on capacity constraints in the European context see Imelda Maher, 'Networking Competition Authorities in the European Union: Diversity and Change', in Claus-Dieter Ehlermann and Isabela Atanasiu (eds), European Competition Law Annual 2002: Constructing The EU Network Of Competition Authorities (Oxford: Hart Publishing, 2004) 223-36.

${ }^{84}$ More on the issue of gathering evidence located abroad see Noonan, above n 75, at 517-34; Sweeney, above $\mathrm{n}$ 3 , at 251-62.

${ }^{85}$ Becker, above n 10, at 111-12. See also Sokol, above n 16, at 974.

${ }^{86}$ Eleanor M. Fox, 'Antitrust without Borders. From Roots to Codes to Networks', in Andrew T. Guzman (ed), Cooperation, Comity, and Competition Policy (Oxford: OUP, 2011) 274.

${ }^{87}$ Hawk notes in the context of developing countries that 'predatory cartels composed of foreign producers may be more frequent in developing countries where local cartel bans may be inadequate and home country bans are inapplicable.' Compare Barry E. Hawk, 'International Antitrust Policy and the 1982 Acts: The Continuing Need for Reassessment', 51 Fordham Law Review 201 (1982), at 248.

${ }^{88}$ Compare Michal S. Gal, 'Extraterritorial Application of Antitrust- The Case of a Small Economy: Israel', in Andrew T. Guzman (ed), Cooperation, Comity, and Competition Policy (Oxford: OUP, 2011) 97-120; Michal S. Gal, 'The Effects of Smallness and Remoteness on Competition Law - The Case of New Zealand', 14 Competition \& Consumer Law Journal 292 (2007).

${ }^{89}$ The African proverb 'Speak softly and carry a big stick, you will go far' associated with US President Roosevelt foreign policy seems to adequately characterize extraterritoriality, where the judicial process plays the role of the soft speech and the economic or political importance does the work of the big stick. When the latter is missing, the former stops being effective.
} 
Even in the case of states with well-developed antitrust regimes, necessary resources and various cooperation agreements in the field of enforcement, extraterritoriality ${ }^{90}$ may be obstructed by state-related avoidance techniques. ${ }^{91}$ Depending on the scope of a state involvement in the challenged conduct, the effort of bringing a foreign export cartel to a court may be either blocked on the jurisdictional level (principle of nonjusticiability / political question doctrine, the foreign state immunity doctrine), or significantly hindered by the available defences on merits (the act of state doctrine, foreign state compulsion). ${ }^{92}$ The bulwark of 'sovereignty' severely impedes the possibility of relying on extraterritoriality in transnational antitrust litigation involving or implicating foreign states. This is particularly so in cases concerning exploitation and exportation of natural resources, which traditionally have been seen as falling within the state domain. ${ }^{93}$

The existence of export cartels exemplifies a gap in the present regulatory framework, which is ill-equipped to handle such foreign anticompetitive challenges. ${ }^{94}$ What seems to be lacking it a "cosmopolitan conception"95 which would allow a refocus of national competition laws from national to global welfare, taking into consideration foreign (outbound) consequences of domestic anticompetitive agreements. ${ }^{96}$ Against this backdrop, the present

\footnotetext{
${ }^{90}$ Some jurisdictions, especially the US, apart from prescriptive jurisdiction require their courts to establish personal jurisdiction over defendants. They demand an adequate nexus between the court's territorial jurisdiction and the defendant. In the US this issue it intertwined with the due process requirement as provided under $5^{\text {th }}$ and $14^{\text {th }}$ Amendments to the federal Constitution. Therefore the reach of the prescriptive jurisdiction may be limited by the scope of personal jurisdiction. See Mark R. Joelson, An International Antitrust Primer: a Guide to the Operation of United States, European Union, and Other Key Competition Laws in the Global Economy, 3rd ed. (Alphen aan den Rijn: Kluwer Law International, 2006) 87-90; Gary Born, International Civil Litigation in United States Courts: Commentary \& Materials, 3rd ed. (The Hague: Kluwer Law International, 1996) 67-78.

${ }^{91}$ Spencer Weber Waller, et al., Special Defenses in International Antitrust Litigation (Chicago: ABA Antitrust Section, 1995); Marek Martyniszyn, 'Avoidance Techniques: State Related Defences in International Antitrust Cases' (CCP Working Paper No. 11-2, 2011), available at http://ssrn.com/abstract=1782888 (visited 7 January 2012).

${ }^{92}$ In case of Australia the reliance on extraterritoriality in actions for damages is not automatic, but requires (under Section 5(3) of Competition and Consumer Act 2010) a prior ministerial consent. The Minister is required to grant the consent apart from a situation when the challenged conduct was required or specifically authorized by the law of the state in which it took place and the consent would not be in the national interests. Therefore a case against a foreign export cartel involving important Australian trade partner may not be at all possible in this jurisdiction. See Competition and Consumer Act 2010; Australian Government- The Treasury, 'Guidance on Obtaining Ministerial Consent to Rely on Extraterritorial Conduct in Private Proceedings', January 1, 2011 2011, available at http://www.treasury.gov.au/documents/1929/PDF/Guidance.pdf (visited 7 January 2012), compare OECD, 'Competition Policy in Australia', 2010, para. 3.3.1, available at http://www.oecd.org/dataoecd/63/61/44529918.pdf (visited 7 January 2012).

${ }_{93}^{93}$ See generally Nico J. Schrijver, 'Natural Resources, Permanent Sovereignty over', in Rüdiger Wolfrum (ed), The Max Planck Encyclopedia of Public International Law, online ed. (OUP, 2010).

${ }^{94}$ In a similar vein Fox, above n 86, at 274; Eleanor M. Fox, 'International Antitrust and the Doha Dome ', 43 Virginia Journal of International Law 911 (2003), at 919.

${ }^{95}$ Fox, above $\mathrm{n} 77$, at 366.

${ }^{96}$ Fox and Ordover, above n 63, at 19-20; Drexl, above n 60, at 431.
} 
legal status of export cartels gives the impression they are a living reminiscence of beggarthy-neighbour policies ${ }^{97}$ and remain a challenge for targeted jurisdictions.

\section{Case Studies}

This section outlines a few examples of cases where export cartels were challenged by extraterritorial application of competition laws in targeted states. It is not an analysis of a statistically representative sample, but rather an effort to partly fill in the empirical gap and better inform the discussion on export cartels by presentation of recent and still little-known case law. These cases, while involving different contexts, point out to various problems involved in attempts of unilaterally addressing export cartels. They present both the NorthSouth and South-North dimensions. ${ }^{98}$ First two cases deal with the same American soda ash export cartel, which was challenged, inter alia, in India and in South Africa. Both jurisdictions attempted to apply their competition laws extraterritorially, with very different outcomes. In India the case against the cartel failed. The Indian Supreme Court rejected, on a textual basis, the possibility of extraterritorial application of domestic competition law. Furthermore, the US government brought to play considerable political pressure while the case was awaiting decision. In South Africa the competition authority had the legal capacity to apply its law extraterritorially. The prolonged litigation ended with a settlement, according to which the cartel paid a considerable fine and withdrew from the market. From the perspective of antitrust enforcement: a success story.

The three cases that follow offer the South-North perspective: Chinese export cartels affecting markets in the US. In these three recent cases defendants are generally (sometimes their status is unclear) state-owned enterprises and there is a considerable state involvement,

\footnotetext{
97 Wunderlich and Warrier describe beggar-thy-neighbour policies as 'strategic economic policies that are designed to enhance domestic welfare by promoting trade surpluses that can be only realised at the expense of other countries'. Jens-Uwe Wunderlich and Meera Warrier, A Dictionary of Globalization (London: Taylor and Francis, 2009) 47-48.

${ }^{98}$ The North-North export cartel cases are rare. It may well be that the North, in general, is so economically integrated that companies capable of organizing export cartels affecting markets in other states in the North are already present in those markets and any transnational cartel cases in this regard would involve international and not export cartels. A rare example of a North-North export cartel case was the 2003 Irish competition authority investigation of eleven US export cartels (the Webb-Pomerene Associations, see n 99 below) registered with the Federal Trade Commission. In effect some of these entities made commitments indicating that they were not involved in trade into Ireland, other changed their by-laws or informed that they had disbanded. The Authority had concerns only with regard to one cartel. Yet the change of the leadership of the Authority led to the reorientation of its focus and it seems that the issue was not followed up. Compare The Competition Authority, '2004 Annual Report', 2004, $\quad$ available http://www.tca.ie/images/uploaded/documents/annualreport2004.pdf (visited 7 January 2012); Colm Keena, 'Competition Body Investigates US Group over Possible Cartel Activity', The Irish Times, 19 March 2005.
} 
with the Chinese government actively supporting or forcing cartel creation and its operations. Although none of these cases has been settled yet, they raise a number of issues in the context of challenging transnational anticompetitive conduct with a foreign state involvement. Moreover, they point out to the interrelated trade dimension, as the conduct at stake was also challenged within the WTO framework, providing new dynamics into the issue of export cartels.

\section{A. American soda ash export cartel cases}

The American Soda Ash Export Cartel (ANSAC), an export cartel established in 1984 and registered under Webb-Pomerene Act, ${ }^{99}$ faced legal action for its anticompetitive conduct in various jurisdictions. After the European Commission found ANSAC had breached EU competition law by price fixing in $1990,{ }^{100}$ ANSAC members organized another export association for the sake of exports to the EU, which focuses only on logistics related activities. ${ }^{101}$ More recently, ANSAC was accused of price-fixing in India and in South Africa. ${ }^{102}$ This section analyzes these two cases.

\section{The Indian case: A tale with a dramatic punchline}

In 1996 the Alkali Manufacturers Association of India (AMAI), which represents major producers of soda ash in India filed a complaint and applied for a temporary injunction (to stop imports) with the Indian antitrust authority, the MRTP Commission, against ANSAC for various infringements of the competition law. The applicable law was then the Monopoly and Restrictive Trade Practice Act of 1969 (the MRTP Act). ${ }^{103}$ In essence ANSAC, who attempted to enter Indian market for the first time, was accused of predatory pricing (selling below the costs). ANSAC, allegedly to circumvent Indian competition law tried to sell its products indirectly via a Singaporean entity. In response to the AMAI action, the

\footnotetext{
${ }^{99}$ The Webb-Pomerene Act provides for an exemption for US export trade associations, ergo export cartels, from domestic antitrust law. See Wilbur L. Fugate, 'The Export Trade Exception to the Antitrust Laws: The Old Webb-Pomerene Act and the New Export Trading Company Act', 15 Vanderbilt Journal of Transnational Law 673 (1982). For the listing and fillings of the registered entities under the Webb-Pomerene Act see http://www.ftc.gov/os/statutes/webbpomerene/index.shtm (visited 7 January 2012).

${ }^{100}$ European Commission, 91/301/EEC, Decision of 19 December 1990 relating to a Proceeding under Article 85(1) of the EEC Treaty, IV/33.016- Ansac, OJ L152 54-60 (1991).

${ }_{101}$ See below text accompanying notes 141-142.

102 ANSAC was also fund abusing dominant position in Venezuela. See Ignacio de León, An Institutional Assessment of Antitrust Policy: the Latin American Experience (Alphen aan den Rijn: Kluwer Law International 2009) 371-72. Bhattacharjea, also writing on export cartels, looked into ANSAC cases in the EU, South Africa, India and Venezuela. Compare Bhattacharjea, above n 25.

${ }^{103}$ The Monopolies And Restrictive Trade Practices Act, No. 54 of 1969, 27 December 1969, later replaced. See below note 116 .
} 
Commission instituted an inquiry and ordered an ex patre interim injunction against ANSAC ${ }^{104}$ in accordance with section $12 \mathrm{~A},{ }^{105}$ on the basis of a prima facie view that ANSAC was engaged in restrictive trade practices. ${ }^{106}$ In 1997 the Commission rejected ANSAC's petition for vacating the injunction. It based its jurisdiction on the section $14^{107}$ claiming that the ANSAC was carrying out part of its activities in India. ${ }^{108}$ In 2000 the Commission upheld the injunction and dismissed the ANSAC new argument that the case concerned dumping and therefore the Commission did not have jurisdiction. ${ }^{109}$

The case was appealed to the Supreme Court, ${ }^{110}$ which found that the MRTP Act conferred no extraterritorial jurisdiction. ${ }^{111}$ Under the textual interpretation adopted by the court jurisdiction existed only after importation of the goods, while in this case the goods were only intended to be imported. Moreover, at least one of the parties involved in the

\footnotetext{
${ }^{104}$ Alkali Manufacturers Association of India v. American Natural Soda Ash Corporation \& Others, Order from September 9, 1996 (1998) 3 CompLJ 173 MRTPC.

105 Section 12A(1) allowed for temporary injunction 'where during an inquiry before the Commission, it is proved (...) that any undertaking or any person is carrying on, or is about to carry on (...) unfair, trade practice and such (...) practice is likely to affect prejudicially the public interest or the interest of any trader (...) or of any consumer or consumers generally (...).' Section 37 of the MRTP Act allowed the Commission to investigate and prohibit any restrictive trade practice (RTP) after funding it 'prejudicial to the public interest'. Section 38, on the other hand, provided a presumption, considering RTPs prejudicial to the public interest if not justified under so-called 'gateways', a list of defenses under section 38, which were not investigated in this case.

${ }^{106}$ In the injunction the Commission referred to section 33, which defined 'Registrable agreements relating to restrictive trade practice', classifying the conduct as falling under section 33(1)(j): 'any agreement to sell goods at such prices as would have the effect of eliminating competition or a competitor'. Later it seems to have reclassified the conduct into falling under section 33(1)(d) 'any agreement to purchase or sell goods or to tender for the sale or purchase of goods only at prices or on terms or conditions agreed upon between the sellers or purchasers'.

107 Section 14 'Orders where party concerned does not carry on business in India: Where any practice substantially falls within [monopolistic, restrictive, or unfair, trade practice, relating to the production, storage, supply] distribution or control of goods of any description or the provision of any services and any party to such practice does not carry on business in India, an order may be made under this Act with respect to that part of the practices which is carried on in India.'

108 The Commission analyzed the intricacies of the planned transaction and found the there was a sufficient nexus between the Indian consumers and ANSAC. There was business correspondence between some of the Indian consumers and ANSAC quoting a specific price of soda ash, which was reflected in letters of credit opened by Indians producers in favour of the Singaporean entity (which ANSAC used arguable in circumvention of Indian law) in an Indian bank. Moreover, there was a bill of lading indicating a port in the US as a port of loading and an Indian port as a port of discharge. Alkali Manufacturers Association of India $v$. American Natural Soda Ash Corporation \& Others, Order from June 10, 1997 (1998) 3 CompLJ 152 MRTPC.

109 Aditya Bhattacharjea, 'Predation, Protection and the 'Public Interest", 35 Economic and Political Weekly 4327 (2000), at 4329. Bhattacharjea points out also another issue in the backdrop of this case: a possible existence of a domestic cartel of soda ash producers on the Indian market. See ibid, at 4328-29.

${ }^{110}$ Haridas Exports v. All India Float Glass Manufacturers' Assn., 6 SCC 600 (The Supreme Court 2002).

${ }^{111}$ Section 14 'Orders where party concerned does not carry on business in India' of the MRTP Act:

Where any practice substantially falls within [monopolistic, restrictive or unfair, trade practice, relating to the production, storage, supply, (Ins. by Act 58 of 1991, sec. 7)] distribution or control of goods of any description or the provision of any services and any party to such practice does not carry on business in India, an order may be made under this Act with respect to that part of the practices which is carried on in India.' For more on the issue of extraterritoriality in antitrust and its limitations see above text accompanying notes 77-89.
} 
anticompetitive conduct have to be carrying out business in India. ${ }^{112}$ Therefore it can be argued that the Supreme Court could have interpreted the law in a different way, finding ANSAC within the Commission's jurisdiction. The lack of explicit, textual basis providing for extraterritorial jurisidciton in competition law exposed therefore India to vulnerability.The issue at stake was found beyond India's competition law jurisdictional reach and ANSAC won the appeal. ${ }^{113}$

The appeal was heard along with an appeal in another case, dealing with Indonesian manufacturers and exporters of float glass, raising similar issues of extraterritorial application of Indian competition law. In this context the court addressed the issue of the interface of competition and anti-dumping law. The firms argued that Art. 18.1 of the WTO AntiDumping Agreement, ${ }^{114}$ to which India is a signatory, precludes the Commission's jurisdiction in a case involving predatory pricing. The court considered the jurisdiction of the Commission not to be 'ousted' by the national legislation implementing the Anti-dumping Agreement and noted that both sets of rules, on anti-dumping and competition, 'operate in different and distinct spheres. ${ }^{115}$ It recognized that the anti-dumping and competition rules serve different purposes and are administered in a different way. ${ }^{116}$ The MRTP Act was later replaced with the Competition Act of 2002, which explicitly provides for extraterritorial jurisdiction in antitrust cases. ${ }^{117}$

After ANSAC was banned from importing to India, it started lobbying for its case in the US and placed an official complaint with the US Trade Representative (USTR), arguing that India 'failed to provide the US equitable and reasonable access' to its market. ${ }^{118}$ This issue was discussed between the Indian Minister of Commerce and Industry and the US

\footnotetext{
${ }^{112}$ Haridas Exports v. All India Float Glass Manufacturers' Assn., above n 110, at 10-14.

${ }^{113} \mathrm{Ibid}$, at 10 . The court noted as well that a temporary injunction could be issued only after it is proved that the respondents are carrying or are about to carry on a restrictive trade practice which will be prejudicial to the public interest or to the interest of traders. Ibid, at 18-19.

114 Art. 18.1: 'No specific action against dumping of exports from another Member can be taken except in accordance with the provisions of GATT 1994, as interpreted by this Agreement.'

${ }_{115}^{115}$ Haridas Exports v. All India Float Glass Manufacturers' Assn., above n 110, at 14.

${ }^{116}$ Ibid. Compare Bimal N. Patel, India and International Law (Leiden: Martinus Nijhoff, 2008) 44-45.

${ }^{117}$ Section 32 of the Competition Act of 2002 provides for extraterritorial jurisdiction where the alleged anticompetitive arrangement has a foreign element (or is wholly foreign) and has or is likely to have an 'appreciable adverse effect' on an Indian market. Moreover, the amendment to the Act introduced in 2007 provides for interim measures against imports contravening substantial provisions of the Act. See The Competition Act, No. 12 of 2003 (14 January 2003), as amended. Compare Shohit Chaudhry and Kartinkey Mahajan, 'The Case for an Effective Extraterritorial Jurisdiction of Competition Commission of India in Light of International Practices', 32 European Competition Law Review 314 (2011).

118 'US to Review Grant of GSP to India', Businessline, 31 January 2001.
} 
Secretary of State, while the case was under appeal. ${ }^{119}$ As it has not been settled at the intergovernmental level, the USTR announced a review of the US Generalized System of Preferences (GSP) for India. The GSP provides for duty-free imports of defined goods and is designed to benefit developing countries. The review was intended to determine whether India offered 'equitable and reasonable market access for US goods and services' and could have ended with the withdrawal of the preferences. ${ }^{120}$ Media estimated that the value of the GSP benefits at a couple of hundred million dollars. ${ }^{121}$ At that point the Indian import duties on soda ash were 35 per cent, despite the rate agreed within the WTO framework was 40 percent. ${ }^{122}$ The pressure of the US government on India was such, that the Indian government further lowered custom duties on soda ash down to 20 per cent and removed a previously applicable surcharge of 10 per cent. ${ }^{123}$ After the case was decided by the Supreme Court, whose interpretation prohibited extraterritorial application of Indian competition law in that context, the Office of the USTR considered the positive outcome of the legal dispute the result of its actions. ${ }^{124}$ India, an important developing country with a significant market, seems to have yielded to US political pressure and economic threat.

The Indian ANSAC case suggests that countries introducing or reforming their competition laws should explicitly provide for extraterritorial application of their antitrust laws. Moreover, this case illustrates that when an international legal framework is lacking, political and economic power matter. This case shows that while the area of transnational anticompetitive conduct remains internationally unaddressed, the matter may be dealt with in

\footnotetext{
119 'Ansac Issue Still Hangs After Key US-India Meeting', Chemical Business Newsbase, 31 March 2000.

${ }^{120}$ US to Review Grant of GSP to India, above n 118 ,

121 'India files Response to US Fed Register Notice', Businessline, 22 February 2001.

122 'Withdrawal of Duty-Free Treatment to Soda Ash: India files Response to US Federal Register Notice', Chemical Business Newsbase, 2 March 2001.

123 'Soda Ash: An Unkind Cut', Businessline, 4 March 2001.

${ }^{124}$ Broadbent, Assistant US Trade Representative in its statement before the Senate Subcommittee noted 'One success story is the case where ANSAC was blocked from exporting to India after an accusation of anticompetitive practices. After close consultations with you and others in Congress, Ambassador Zoellick intervened repeatedly with the Indian government to ensure that U.S. exporters were treated in a transparent and fair manner. As a result, the allegation was overturned by the Indian Supreme Court in 2002. U.S. soda ash exporters have since had the opportunity to sell to this important growing market restored.' 'International Trade and the Impact on the US Soda Ash Industry', Hearing before the Subcommittee on International Trade of the Committee of Finance, US Senate, 15 April 2004, HRG 108-527, available at http://finance.senate.gov/library/hearings/download/?id=f0148a8a-1c78-4e76-9776-485ffbf2ec7a (visited 7 January 2012). At the same time it should be clarified that the US government does not intervene each time when a US export cartel is challenged abroad. The relevant provisions providing for export cartels in the US make it crystal clear that they afford, under certain circumstances, immunity only from the US antitrust law. The prime example of a US export cartel challenged abroad without the US administration getting involved is Wood Pulp. See Joined Cases 89, 104, 114, 116, 117 and 125 to 129/85, A. Ahlström Osakeyhtiö and others v. Commission of the European Communities (Wood Pulp), [1988] ECR 5193. Compare Dieter G. F. Lange and John Byron Sandage, 'The Wood Pulp Decision and its Implications for the Scope of EC Competition Law', 26 Common Market Law Reivew 137 (1989).
} 
the political arena as a trade matter, outside the scope of competition law, or any of the existing multilateral regimes.

\section{The South African case: enforcement success story}

The case concerned ANSAC imports to South Africa. It was brought in 1999 by Botash, a Botswanian producer of soda ash, with its Southern African distributor, ${ }^{125}$ who complained to the Southern African competition authority- the Competition Commission, ${ }^{126}$ accusing ANSAC of fixing prices of its exports to South Africa (SA) and market allocation. Unlike the situation in the Indian case, ANSAC was already present on this market when the allegations were brought. The Commission after its investigation referred the case to the Competition Tribunal.

The possibility of an extraterritorial application of the reach of the SA competition law $^{127}$ was itself not challenged. The disagreement concerned the precise extent of its reach. ${ }^{128}$ Section $3(1)$ of the Competition Act provides for jurisdiction over 'all economic activity within, or having an effect within' the SA. ANSAC argued that this provision allows the court to assume jurisdiction only when an anticompetitive, 'deleterious' effects has been established. It further argued that only the net effect of the challenged conduct should be taken into consideration, requiring therefore an analysis of both the anti- and procompetitive effects. ${ }^{129}$ From an ANSAC perspective this issue was important as price-fixing is per se prohibited under Section 4(1)(b) of the Act. The Tribunal did not share this line of argument, considering the wording of Section 3(1) clear and neutral. The court's jurisdiction is assumed when the evidence of 'effects' is established, without investigation into their nature. ${ }^{130}$ This

\footnotetext{
${ }^{125}$ Note: Botswana and South Africa are members of the Southern African Customs Union (SACU), which is the world's oldest custom union. It has five members: the Republic of South Africa, Botswana, Lesotho, Swaziland and Namibia. For more information about SACU see http://www.sacu.int/ (visited 7 January 2012).

${ }^{126}$ The Southern African competition law regime is composed of three independent bodies: the Competition Commission, acting as an investigating body; the Competition Tribunal, the adjudicating body, and the Competition Appeal Court, hearing appeals from the Competition Tribunal. More on this issue see Trudi Hartzenberg, 'Competition Policy and Practice in South Africa: Promoting Competition for Development', 26 Northwestern Journal of International Law \& Business 667 (2006).

${ }^{127}$ Competition Act, No. 89 of 1998, Gov. Gazette Vol. 400, No. 19412 (30 October 1998), as amended. For the consolidated version of the Act, indicating changes see http://www.compcom.co.za/assets/Files/pocket-book2005-R.pdf (visited 7 January 2012). The Act was further amended in 2009, see Competition Amendment Act, No. 1 of 2009, Gov. Gazette Vol. 530, No. 32533 (28 August 2009).

${ }^{128}$ Reasons and Order of the Competition Tribunal of 30 November 2001, Competition Comission v. American Natural Soda Ash Corp (Soda Ash), Cases 49/CR/Apr00 and 87/CR/Sep00, 4.

${ }^{129}$ Ibid, at 6.

${ }^{130}$ Ibid, at 29.
} 
decision was upheld on appeal. ${ }^{131}$ ANSAC sought leave to appeal to the Supreme Court of Appeal of South Africa (SCA). This was the first such an appeal in the SA. ${ }^{132}$ The SCA agreed with lower courts in interpreting Section 3(1) as providing for jurisdiction based on all kinds of effects, not only these adverse. ${ }^{133}$

The hearing before the Competition Tribunal took place in June 2008 and the closing arguments were scheduled for November 2008, but beforehand ANSAC contacted the Commission in order to discuss a settlement. It decided to withdraw from the SA market and, for the purpose of avoiding future litigation, it was willing to admit a contravention of the Act. Both sides agreed on the terms, the settlement was signed and subsequently confirmed by a court order. ${ }^{134}$ ANSAC agreed to make no further sales to the SA and to change its agreement to allow its members to sell individually in the SA, and not to in any way influence its members not to do so. ${ }^{135}$ Moreover, it agreed to pay a penalty representing eight per cent of soda ash annual turnover in the SA. ${ }^{136}$ Therefore the nine-year-long saga of soda ash proceedings, or as Justice Madlanga put it 'a Methuselah of proceedings ${ }^{137}$ ended. In a press release after the settlement ANSAC explained its decision to withdraw by observing that the costs and regulatory difficulties of serving the market made it comparatively less attractive. ${ }^{138}$ This may also explain why ANSAC did not seek alternative solutions through the US Trade Representative.

\footnotetext{
${ }^{131}$ American Natural Soda Ash Corp v. Competition Comission (Soda Ash- the Competition Appeal Court), Case 12/CAC/DEC01 (The Competition Appeals Court of South Africa 2003).

${ }^{132}$ In fact, before the appeal in the Competition Appeal Court took place, ANSAC had already sought an appeal directly in the SCA, but the court refused to hear it at that stage. This time the court accepted the application and delivered its opinion. American Natural Soda Ash Corp v. Competition Comission (Soda Ash- the Supreme Court of Appeal), Case 554/03 (The Supreme Court of Appeal of South Africa 2005). For court's jurisdiction to hear the appeal see ibid, at paras 8-15. For test for leave for appeal see ibid, at paras 16-23.

133 Ibid, at paras 24-29. The SCA found that the Tribunal erred in not admitting evidence allowing to characterize, the conduct for the purposes of determining, whether it falls under Section 4(1)b (per se prohibition). Ibid, at para. 41. The SCA pointed out the need for the Tribunal's clarification of the ambit of the per se prohibition, which should also spell out the extent of evidence admissible for the sake of such determination in particular cases. Ibid, at paras 56-57, 60. For the broader discussion in this context see Kasturi Moodaliyar and Keith Weeks, 'Characterising Price Fixing: A Journey Through the Looking Glass with ANSAC', 11 South African Journal of Economic and Management Sciences 337 (2008).

${ }^{134}$ Order of the Competition Tribunal Confirming the Settlement Agreement of 4 November 2008, Competition Comission v. American Natural Soda Ash Corp (Soda Ash), Case 49/CR/Apr00.

${ }^{135}$ Ibid, at para. 6.1 of the Settlement.

${ }^{136}$ Ibid, at para. 7.1 of the Settlement.

${ }^{137}$ Reasons and Oder of the Competition Tribunal of 13 August 2008, American Natural Soda Ash Corp v. Competition Comission (Soda Ash), Case 49/CR/Apr00, para. 1. Methuselah is a biblical character who lived nine hundred sixty nine years.

${ }^{138}$ ANSAC, 'ANSAC Reaches Settlement in South Africa', 4 November 2008.
} 
Despite the assurances of the President of ANSAC in his testimony in this case that it would not happen, ${ }^{139}$ some of ANSAC members after its withdrawal kept supplying market on their own. ${ }^{140}$ Looking at the levels of soda ash export from the US to the South Africa (see the chart below), it may be argued that the litigation had a negative impact in the short-term. A significant drop in US exports took place in 2002, the Competition Tribunal having issued orders against ANSAC in 2001. Still, the levels of exports increased steadily in the following years, reaching very high levels. In fact 2010 seems to be the best year in fifteen years from the perspective of exported quantities. At the same time these raw numbers need to be read with caution as they reflect the whole business environment as such, and not only the impact of the litigation. In any case it seems that from the supply side, the withdrawal of ANSAC not only did not affect market negatively in the medium-term, but actually improved the supply.

\section{US Exports of Soda Ash to the South Africa}

(in thousand metric tons)

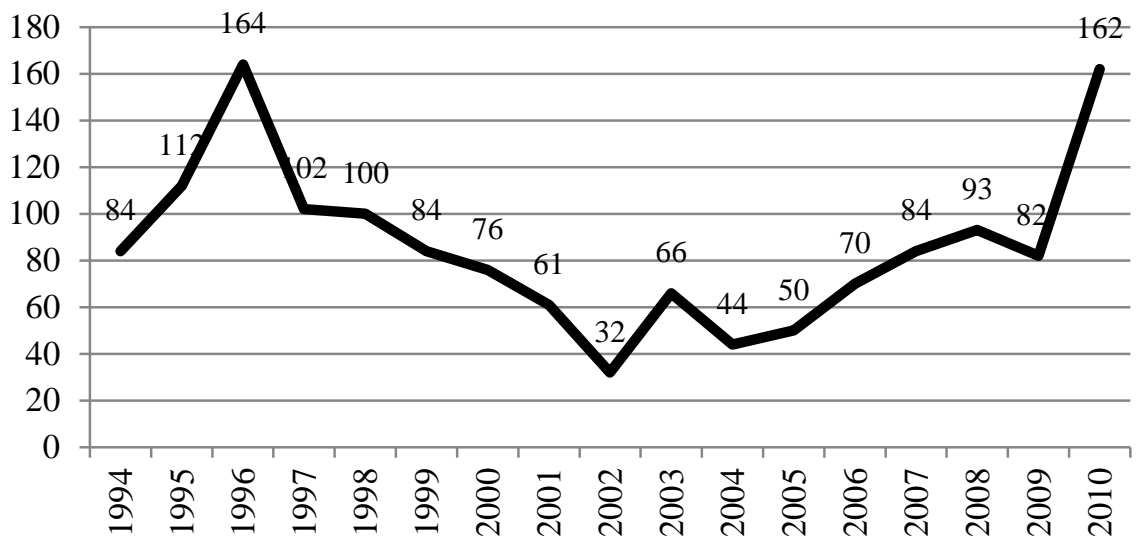

Source: US Department of the Interior and US Geological Survey, available at http://minerals.er.usgs.gov/minerals/pubs/commodity/soda_ash/ (visited 7 January 2012).

It is also worth noting that the when ANSAC was found in breach of EU competition law in $1990,{ }^{141}$ its members established the American-European Soda Ash Shipping Association (AESSA). This new entity, although also registered as an export cartel under the Webb-Pomerene Act, coordinates only logistics-related activities, such as shipping and storage, allowing its members achieve economies of scale while remaining in line with the

\footnotetext{
${ }^{139}$ Witness Statement of John M. Andrews, American Natural Soda Ash Corp v. Competition Comission (Soda Ash), Case 49/CR/Apr00, paras 59, 66-67.

${ }^{140}$ For example FMC Wyoming Corporation and, more recently, Solvay operate in the South Africa, with FMC responsible for majority of the export to the SA. For more information see http://www.fmc.com/ and http://www.solvay.com/ (visited 7 January 2012). Solvay in fact left ANSAC in 2008. Compare Solvay, 'First Successful Export Shipments from the US', 31 January 2011, available at http://www.solvaychemicals.com/EN/News/Export_USA.aspx (visited 7 January 2012).

${ }^{141}$ European Commission, above n 100.
} 
EU competition law. ${ }^{142}$ It is possible that the relative lack of importance of the SA market to ANSAC meant its members were not interested in a similar solution in this case. One should note that while the case was ongoing, for nine years, as there was no injunction in force ANSAC kept exporting to the SA and its members were bound by the agreement not to sell individually.

For a thorough assessment of the effect of the cartel on prices a comprehensive analysis of price levels of soda ash would be necessary. Such exercise lies beyond the scope of this paper, yet a general perspective may be offered. Was soda ash any less or more expensive after ANSAC left the market? If one looks only at the US export prices (free alongside ship) to the SA, then the drop is visible (see the chart below). In 2010 the price dropped down to the level noted only once in the last fifteen years. Furthermore, when compared with US export prices to Belgium (where ANSAC was not operating ${ }^{143}$ ) and to Argentina (where ANSAC is present), both importing from the US more soda ash on average than SA, ${ }^{144}$ it is clear that in the period 1996-2010 Argentinean prices were generally higher than export values to SA, and that this gap widened significantly in the last few years. In case of comparison of the US export values to Belgium/SA it is interesting to note similar changes since 2007. Moreover, in 2009 US export prices to the SA where only slightly higher (four per cent), while in 2010 they were twelve per cent lower than US export prices to Belgium. Furthermore, from 1996 until 2006 the US export price to the SA was generally higher than the average US export price, while since 2007 the relation changed and the US export price to the SA in each year was becoming lower as compared to the average US export price.

\footnotetext{
${ }^{142}$ Dennis S. Kostick, '2008 Minerals Yearbook: Soda Ash', US Department of the Interior, US Geological Survey, 2008, available at http://minerals.usgs.gov/minerals/pubs/commodity/soda_ash/myb1-2008-sodaa.pdf (visited 7 January 2012).

${ }^{143}$ See above text accompanying note 141 .

${ }^{144}$ Belgium and Argentina are used in this comparison for illustrative purposes. There are considerable, regular exports of US soda ash to these two countries: bigger than in case of SA, yet neither of these countries is a main US soda ash export market.
} 
US Export Prices

(per metric tone, in dollars, f.a.s.)

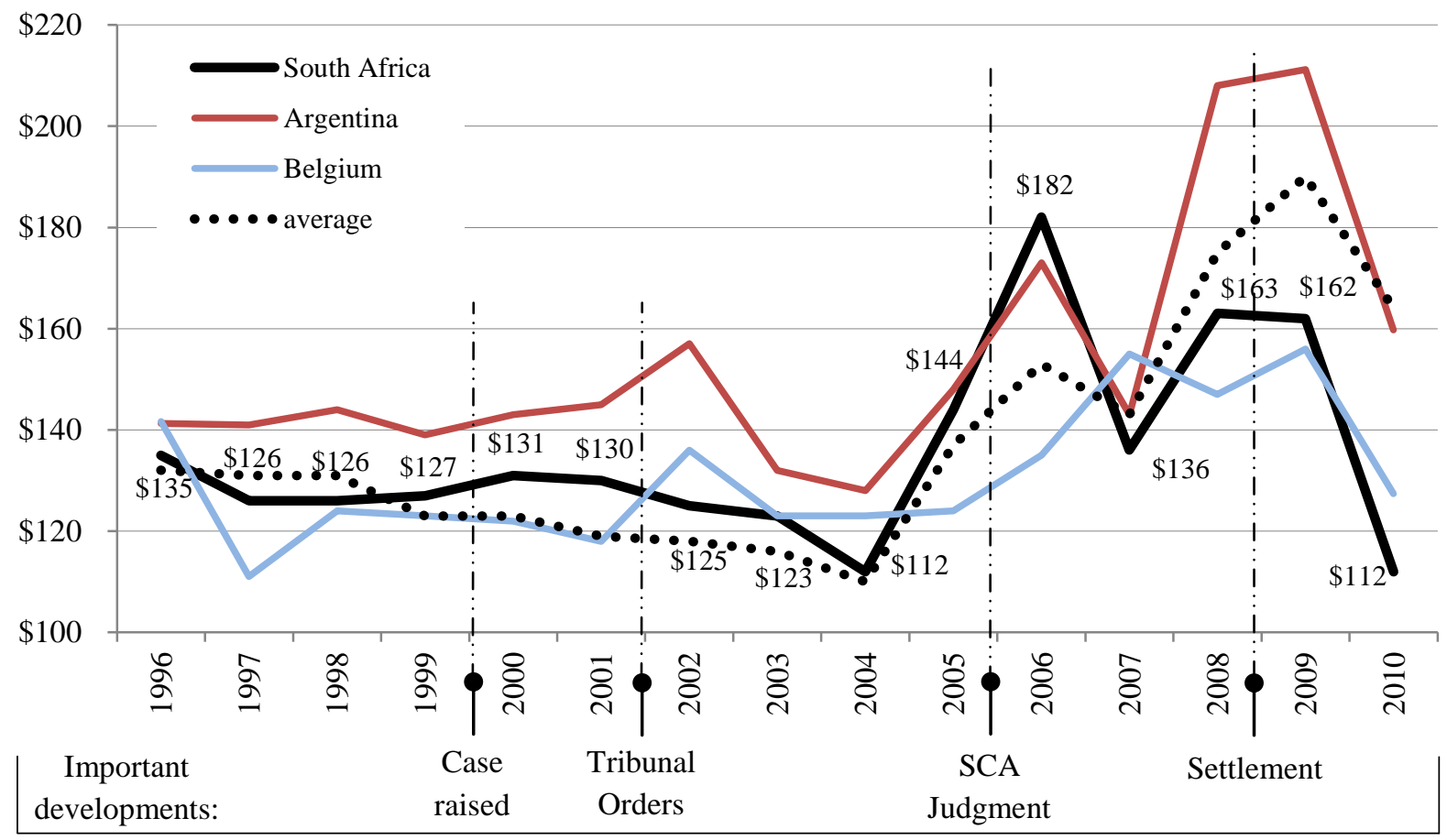

Source: US Department of the Interior and US Geological Survey, available at http://minerals.er.usgs.gov/minerals/pubs/commodity/soda_ash/ (visited 7 January 2012).

One can also look at the difference between the US export price to the SA (which includes the transportation and insurance costs) and the average annual value of the soda ash in the US. The latter is not a price 'but rather the value of the combined revenue of California and Wyoming bulk, dense soda ash sold on an f.o.b. plant basis at list, spot, or discount prices, on long-term contracts, and for export, divided by the quantity of soda ash sold' ${ }^{145}$ It yet may serve as a proxy, even if imperfect, for the sake of the illustration of the price relationship (see the chart below). It clearly shows a stable difference persisted for about ten years, yet from 2007 onwards this difference was much smaller, to finally be negative in 2010. In other words in 2010 the US export price to the SA, f.a.s. (free alongside ship), was about 16 dollars lower than the average value of the soda ash sold by the US producers, f.o.b. (free on board). This trend was similar in case of US export prices to Belgium, while the difference between the US export price to Argentina and the average value in the US remained considerable.

${ }^{145}$ Kostick, above n 142, at 70.2. 


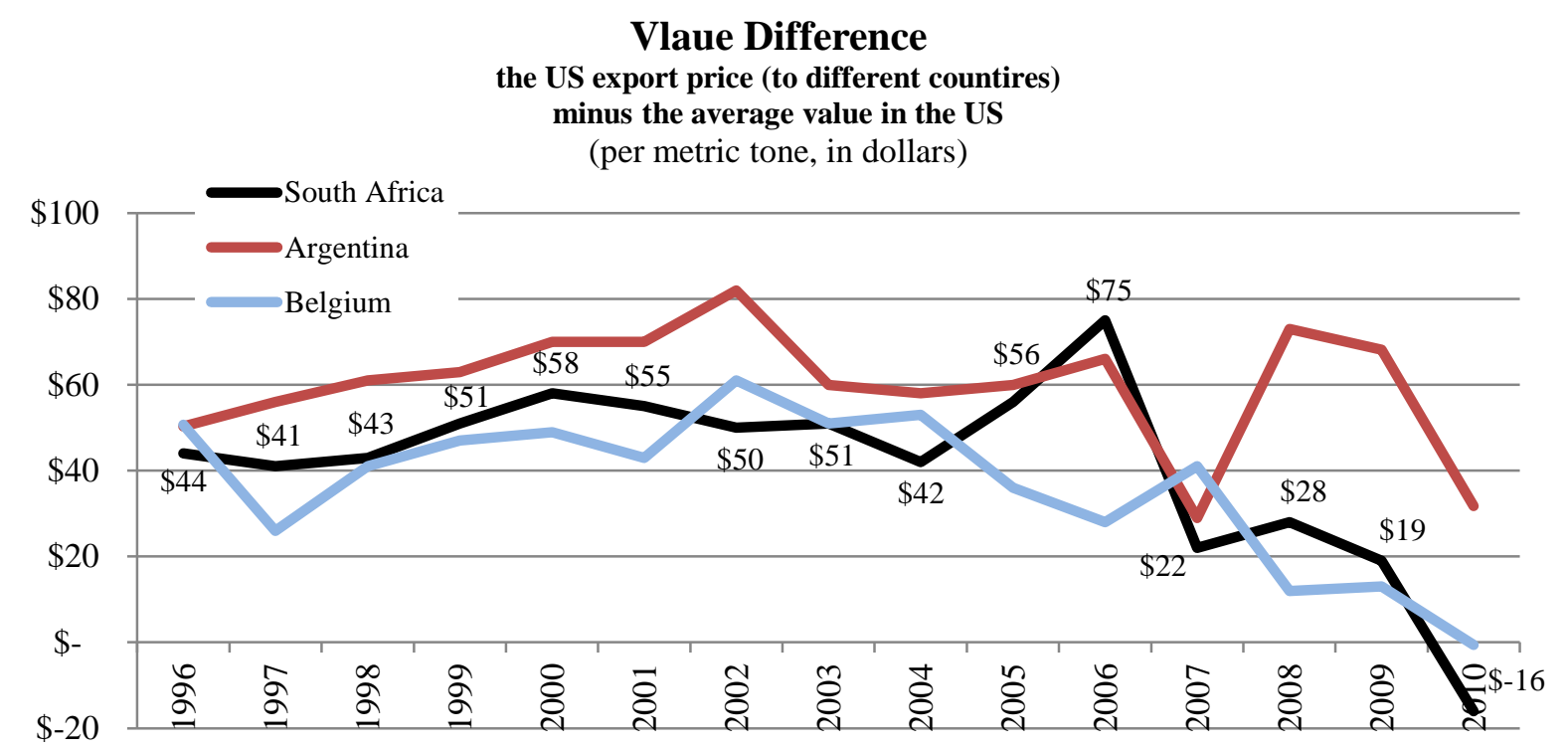

Source: US Department of the Interior and US Geological Survey, available at http://minerals.er.usgs.gov/minerals/pubs/commodity/soda_ash/ (visited 7 January 2012).

This broad comparison allows us to infer that the (extraterritorial) application of the SA competition law led to both better supply and most likely lower prices. The years to come will allow for better assessment in terms of the effect on prices, but the extraterritorial reach of the SA competition law was itself confirmed in practice. The competition authority proved it has the necessary capacity to actively enforce competition law. These are the marks of a success in the area of antitrust law enforcement. This case shows that competition regimes, in principle, when equipped with statutory provisions allowing for extraterritoriality, and when not hindered by internal or external political pressure, are able to unilaterally successfully challenge foreign export cartels.

\section{B. Chinese export cartels}

In the last few years on a number of occasions antitrust actions were brought against Chinese export cartels affecting US markets. In all these cases Chinese authorities are directly involved or at least implicated, and the defendants are in most cases state-owned enterprises. $^{146}$

\footnotetext{
${ }^{146}$ For the potential consequences of state involvement in anticompetitive conduct in general see above text accompanying notes 91-93. For a more detailed analysis of these cases in the context of reliance on the foreign state compulsion see Marek Martyniszyn, 'A Comparative Look on Foreign State Compulsion as a Defence in Antitrust Litigation', 8(2) Competition Law Review (forthcoming, 2012).
} 
These antitrust challenges are embroiled in a broader issue of the unclear interface between trade regulation and competition regimes. Fox and Davis ${ }^{147}$ note that China, in general, is faced with various antidumping actions brought, for example, by the US. The antidumping rules allow, in case of non-market economies, to come up with a 'like' price, for the sake of determination of dumping, by adopting costs structures from more developed market economies. ${ }^{148}$ This makes it relatively easy to establish dumping. The Chinese government in response to antidumping challenges introduced various measures addressing this issue. The price regulation by trade associations, usually supervised by the government, was one of them. ${ }^{149}$ Although addressing the dumping issue, this creates anticompetitive challenges. In effect private antitrust actions are being brought in the US for price-fixing of Chinese exports. Fox and Davis note the irony: the US are able to bring antidumping actions against China, when Chinese firms export goods at low prices (even when such prices reflect the real local costs ${ }^{150}$ ), and when the Chinese government puts in place a regulatory framework to avoid such challenges, Chinese firms may be sued in antitrust actions for fixing prices. ${ }^{151}$ Fox and Davis note that 'China can do what is necessary to formally insulate its responsive prices as an act of state or as sovereign compulsion' raising at the same time the issue of whether China should have to do so. ${ }^{152}$ While acknowledging this wider context, this section looks at these Chinese export cartels cases from the perspective of competition law.

\section{Recent anitrust Challenges}

\footnotetext{
${ }^{147}$ Eleanor M. Fox and Dennis Davis, 'Industrial Policy And Competition- Developing Countries As Victims And Users', Fordham Corporate Law Institute 151 (2006), at 155-58.

${ }^{148}$ Compare Ka Zeng and Wei Liang, 'US Antidumping Actions Against China: the Impact of China's Entry into the World Trade Organization', 17 Review of International Political Economy 562 (2010); Aaron Ansel, 'Market Orientalism: Reassessing an Outdated Anti-Dumping Policy Towards the People's Republic of China', 35 Brooklyn Journal of International Law 883 (2010).

${ }^{149}$ Fox and Davis, above n 147, at 156.

${ }^{150}$ It seems that little has changed in that regard over the years. In 1979 in Pezetel / Polish Golf Carts two actions were brought in the US against a Polish (then still communist, under central planning) state-own enterprise: antidumping and competition cases. The antitrust case involving predatory charges failed on substantive grounds, but in the antidumping proceeding the court, under a then different regulatory regime, was at pains to come up with the 'right' price for Polish golf carts, while there was no golf in Poland and the carts production was solely exported to the US. In the end prices of a small Canadian producer were applied, which did not reflect Polish low costs, and in effect a significant duty was imposed. Compare Loius B. Schwartz, 'American Antitrust and Trading with State-Controlled Economies', 25 Antitrust Bulletin 513 (1980).

${ }^{151}$ Fox and Davis, above $n$ 147, at 176-77.

${ }^{152}$ Fox and Davis opt for limitation of the scope of antidumping, but noting it will be 'slow in coming' they suggest introduction of an international mechanism which would limit firms antitrust liability to compensatory damages only, if they acted within the tight terms of the governmental policy. Compare ibid, at 177.
} 
In Vitamin $C^{153}$ four Chinese manufacturer of vitamin $\mathrm{C}$ and their trade association were accused by US purchasers of price-fixing and limiting exports. They did not deny the allegations, but instead brought a motion to dismiss the case based on the doctrines of foreign sovereign compulsion, the act of state and international comity. ${ }^{154}$ The defences rested on the issue of Chinese government involvement: whether it required the defendants to fix prices. ${ }^{155}$ At that early stage the court found the evidence too ambiguous and denied the defendants' motion. $^{156}$

In this case the Chinese government submitted its first ever amicus in front of a US court. ${ }^{157}$ In its brief the Chinese ministry argued that the trade association was in fact the Chamber of Commerce, under its direct and active supervision, performing governmental functions authorized under Chinese law. Earlier on Chinese authorities issued a notice requiring strict control of vitamin $\mathrm{C}$ production, which led to establishment of the special body, in the Chamber, dealing with this issue. Only its members had the right to export vitamin $\mathrm{C}$ and the charter obliged them to 'voluntarily adjust their production outputs' and to 'strictly execute [an] export coordinated price set by the Chamber and [to] keep it confidential.' There was also a system of sanctions in place, including revocation of the membership or even an indirect threat of a cancellation of the export license. Against this backdrop, the defendants, supported by the Chinese authorities, argued that they were compelled under Chinese law, and although the ministry itself did not set prices, they were unable to export at a non-conforming price. ${ }^{158}$ The court concluded that although such a brief was entitled to 'substantial deference', it was not to be regarded as conclusive. This was particularly so in the instant case, where the documentary evidence provided by the plaintiffs directly contradicted the brief's position. ${ }^{159}$

The plaintiffs claimed there was no single law or regulation forcing a particular price or price agreement at issue. Furthermore, there was evidence showing that the defendants were setting prices themselves by hand voting. In addition, it was argued that defendants set the minimum price, but at the same time undercut each other. ${ }^{160}$ This evidence pointed out to

\footnotetext{
${ }^{153}$ In re Vitamin C Antitrust Litigation, 584 F. Supp. 2d 546 (E.D.N.Y. 2008).

154 Ibid, at 550 .

155 Ibid, at 552 .

156 Ibid, at 559 .

157 Ibid, at 552.

158 Ibid, at 552-54.

159 Ibid, at 557.

${ }^{160} \mathrm{Ibid}$, at 555 .
} 
a complex relationship between the Chinese companies and the Chamber, making it difficult to determine the degree of their independence with regard to prices. ${ }^{161}$

Due to the non-transparent Chinese legal system, frequently relying on administrative instructions, it was unclear 'whether defendants were performing a government function, whether they were acting as private citizens pursuant to governmental directives or whether they were acting as unrestrained private citizens'. ${ }^{162}$ In addition, the court noted that a scenario where the defendants formed the cartel and only then asked for the state recognition was also conceivable. Finally the court considered the records too ambiguous 'to foreclose further inquiry into the voluntariness of defendants' actions' at that stage and the motion to dismiss on the basis of the state-related avoidance techniques was dismissed. ${ }^{163}$

In the most recent decision in this case, of September 2011, the district court denied the defendants a motion for summary judgment based on the foreign compulsion defence. ${ }^{164}$ Although it found the doctrine generally applicable when a party finds itself 'between the rock of its own local law and the hard place of U.S. law', but it found 'no rock and no hard place', in the case at stake. ${ }^{165}$

It became known that the Chinese regulatory framework changed considerably within the considered period (December 2001-December 2008; significant changes- so-called 'selfdiscipline' system- were introduced in 2002). The membership in the Chamber's special body stopped being a prerequisite to receive an export right. ${ }^{166}$ It transpired that there were no penalties for failing to follow the new 'self-discipline' system. ${ }^{167}$ Furthermore, it was established that on one occasion, under the changed regime, one of the cartel members refused to partake in a production stoppage proposed by the other members. As a general manager of the other cartel member commented, it 'unilaterally tore[d] up the agreement [on the shutdown]' ${ }^{168}$ At the next such attempt, the earlier deflecting member participated, but prospects thereof were described as 'not great'. ${ }^{169}$ While the defendants argued that the

\footnotetext{
${ }^{161}$ Ibid, at 556.

${ }^{162}$ Ibid, at 559 .

${ }^{163}$ Ibid. As the plaintiffs field a second amended complaint, adding two more defendants to the case- American corporation, directly purchasing vitamin $\mathrm{C}$ from Chinese manufacturer, the court dismissed the complaint with a leave to replead, making allegations against the new defendants.

${ }^{164}$ In re Vitamin C Antitrust Litigation, No. 06-MD-1738 (E.D.N.Y. Sept. 6, 2011).

165 Ibid, at 2.

${ }^{166}$ Ibid, at 11-12.

${ }^{167}$ Ibid, at 53-55.

${ }^{168} \mathrm{Ibid}$, at 12.

${ }^{169}$ Ibid, at 22-23.
} 
company was penalized for its behavior and required to participate in the second shutdown, the documentary evidence did not support these claims. ${ }^{170}$

It is noteworthy that the court in Vitamin $C$ did not rely on the Chinese authorities interpretation of Chinese law, especially its 2009 statement. ${ }^{171}$ In its opinion it did not 'read like a frank and straightforward explanation of Chinese law' but rather 'a carefully crafted and phrased litigation position. ${ }^{172}$ Moreover, the submitted position was contradicted by the factual record ${ }^{173}$ as well as by China's representations to the WTO. ${ }^{174}$ Overall, the court considered the Chinese support 'a post-hoc attempt to shield defendants' conduct from antitrust scrutiny., 175

The court also referred to the related and then pending WTO trade dispute, where it was argued that China by introduction of minimum price requirements for certain raw materials violated its obligations. ${ }^{176}$ In this case, the Panel found in favour of the US, noting that actions undertaken by the relevant chamber of commerce were attributable to China ${ }^{177}$ (on appeal the Appellate Body, on procedural grounds, declared these findings moot and of no legal effect). ${ }^{178}$ The court in Vitamin $C$ did not find its interpretations of Chinese law altered by the WTO Panel's findings. The only measure possibly indicating compulsion concerned the minimum price requirements put in place to avoid the anti-dumping challenges and it was not relied upon by the Chinese authorities to establish compulsion in the case at stake. $^{180}$

In a similar vein in Animal Science ${ }^{181}$ US plaintiffs brought a class action against a number of Chinese companies exporting magnesite-based products to the US for the alleged

\footnotetext{
${ }^{170}$ Ibid, at 23-24, 67-68. In fact it was suggested that the company participate in the production stoppage because of its own technical problems, therefore on economic grounds. Ibid, at 23.

${ }^{171}$ The 2009 statement 'conspicuously' did not cite any of the sources (laws, regulations) supporting the broad assertions about the regulatory regime in place. Furthermore, it made no distinction between the 1997 and 2002 regimes, which clearly differed. Ibid, at 46.

${ }^{172}$ Ibid.

${ }^{173}$ Ibid, at 47 .

${ }^{174}$ Ibid, at $15-16,46$.

${ }^{175}$ Ibid, at 47.

${ }^{176}$ See below text accompanying notes 192-200.

${ }^{177}$ Panel Report, China-Measures Related to the Exportation of Various Raw Materials, above n 72, para. 7.1096.

${ }^{178}$ See below text accompanying notes $202-205$.

${ }^{180}$ Vitamin $C I b$, above n 164, at 58-60.

${ }^{181}$ Animal Science Products v. China Nat. Metals \& Minerals Import \& Export Corp., 702 F. Supp. 2d 320

(D.N.J. 2010).
} 
price-fixing. The defendants brought a motion to dismiss, invoking state-related defences: act of state doctrine, the foreign state compulsion, and also comity considerations. ${ }^{182}$

In Animal Science the court faced a very similar issue to the one in Vitamin $C$ case. The Chamber of Commerce, a 'governmental appendage' 183 empowered to administer the export licenses, was involved in setting the minimum prices for the exported products. There was also a threat of severe punishment in place in case of non-compliance. ${ }^{184}$ In this case the court found that government compulsion lasted for a long time and was achieved not by a particular act, but was rather created by a legal regime, employing 'various regulatory mechanisms producing a composite effect of a never-ceasing correlation between the minimum price requirement and punitive measures for non-compliance with it'. ${ }^{185}$ It was established that the Chinese government compelled the defendants, and forced upon them ' $a$ ' minimum price. ${ }^{186}$ Yet the court noted that if the actual price figures were never set, or set but left unknown to the defendants and to the authorities enforcing the minimum price requirement, ${ }^{187}$ then any price-fixing agreement is to be treated as a private one, outside the realm of sovereign defences. Similarly, if the prices were known to the defendants, it is still possible that they have entered into supra-minimum price agreements. In such a case, these agreements could be illegal under US antitrust, irrespective of whether the Chinese authorities had the right to enforce them. ${ }^{188}$ The district court dismissed the complaint after finding that the plaintiffs failed to establish court subject-matter jurisdiction. Leave to amend the complaint was granted, ${ }^{189}$ but the plaintiffs declined this and appealed. The Third Circuit

\footnotetext{
182 The action was originally brought in 2005 , but the first two years of the litigation concerned the matter related to the service of process. In 2008 the case was reassigned and further proceedings took place, the complaint was repleaded, finally leading to the discussed court's opinion.

${ }^{183}$ Animal Science, above n 181, at 78.

184 Ibid, at 80 .

${ }^{185}$ Ibid, at 87.

${ }^{186}$ Ibid, at 95 .

${ }^{187}$ The court has established that the Chinese government compelled the defendants and forces upon them ' $a$ ' minimum price. Yet it is still possible that the factual price- 'the' price- was in fact never set by the government (therefore 'the price' equals zero), or that it was set, but never communicated to the defendants (therefore, again, 'the price' equals zero). In any of such cases, any agreements among the defendants fixing the price on any level would not allow defendants to rely on the sovereign compulsion defence.

${ }^{188}$ Animal Science, above n 181, at 96.

${ }^{189}$ The complaint was dismissed (a) with prejudice with regard to the claims based on the 'effects' exception to the Foreign Trade Antitrust Improvements Act (the 'jurisdictional bar' requiring the direct, substantial, and reasonably foreseeable effect on US commerce was not met by the plaintiffs); (b) without prejudice to claims invoking court jurisdiction under the introductory clause of the FTAIA (making the FTAIA 'jurisdictional bar' inapplicable in cases where defendants are importers). Ibid, at 362-63, 83.
} 
vacated the district court decision on jurisdictional issues and the case was remanded for further proceedings on merits. ${ }^{190}$

The district court in Animal Science, compared to Vitamin $C$, was much more thoughtful about the nature of the Chinese regulatory regime. This is a welcome development. It remains to be seen how the court addresses the issue of foreign sovereign compulsion defence, especially in light of the intervening opinion in Vitamin $C$.

Similarly to Vitamin C and Animal Science, in $\operatorname{Resco}^{191}$ a complaint was brought by a US firm against Chinese defendants for their alleged price-fixing of exports of bauxite. The facts are similar to those in the other two cases, as are the arguments of the defense, the core being the invocation of foreign sovereign compulsion. In this case the proceedings were stayed in the anticipation of the outcome of the proceedings brought by the US against China within the WTO dispute settlement framework concerning China's export restrictions on various raw materials, including bauxite. One of the measures complained of by the US is the very issue of price requirements. ${ }^{192}$ The US argued that those are the actions of the Chinese government, as the respondents in Resco claim. Although the decisions of the Dispute Settlement Body are not binding upon the court, the findings may at least simplify the analysis.

The Panel report in this case was circulated to WTO members in July $2011 .^{193}$ The Panel found only six measures related to minimum export price requirement within its frame of reference. These were the measures, such as charters or regulations of chambers of commerce which, as it was pointed out, were related to in the domestic antitrust proceedings in Vitamin $C{ }^{194}$ The complainants alleged that China enforces minimum export prices through a system of 'self-discipline' underpinned by penalties imposed on non-comforting

\footnotetext{
${ }^{190}$ The Third Circuit held that the FTAIA does not impose a jurisdictional bar (referring to adjudicative jurisdiction, that is jurisdiction of the courts), but instead a substantive merit limitation. Animal Science Products v. China Nat. Metals \& Minerals Import \& Export Corp., 2011-2 Trade Cas. (CCH) P77,566 (3rd Cir. 2011).

${ }^{191}$ Resco Products v. Bosai Minerals Group, 2010-1 Trade Cases P 77,061 (W.D. Pa. 2010).

192 'Further, through its ministries and other organizations under the State Council as well as chambers of commerce and industry associations, China administers the price requirements in a manner that restricts exports and is not uniform, impartial, and reasonable.' China-Measures Related to the Exportation of Various Raw Materials, Request for the Establishment of a Panel by the United States, WT/DS394/7, November 9, 2009, available at http://docsonline.wto.org/imrd/directdoc.asp?DDFDocuments/t/WT/DS/394-7.doc (visited 7 January 2012), 6. In December 2009 the single Panel was established to examine this dispute together with similar complaints brought by the European Union and Mexico against China. For the key developments in the dispute see http://www.wto.org/english/tratop_e/dispu_e/cases_e/ds394_e.htm (visited 7 January 2012).

${ }^{193}$ Panel Report, China-Measures Related to the Exportation of Various Raw Materials, above $\mathrm{n} 72$.

${ }^{194}$ Ibid. paras 7.991, 7.995, 7.1001.
} 
exporters as well as penalties imposed on authorities granting licenses to non-comforting exporters. ${ }^{195}$ In this regard references were made to all the above mentioned pending domestic antitrust proceedings (Vitamin C, Animal Science, Resco). ${ }^{196}$ The measures were found attributable to China, ${ }^{197}$ and of a type that may be challenged under Article XI:I GATT. ${ }^{198}$ Although China argued that the export price control was repealed in 2010, the Panel looked at the measures that were in force when it was established (December 2009). It agreed with the approach followed in Japan- Trade in Semiconductors and it considered the authority to determine the export prices and require exporters to adhere to them, under the thread of strict penalties or export license revocation, as potentially trade restrictive and found 'the very potential to limit trade' [emphasis in the original] sufficient to constitute a restriction prohibited under Article XI:1. ${ }^{199}$ Thereby China was found in violation of its WTO obligations. China appealed the findings. ${ }^{200}$

The Appellate Body in its recent report ${ }^{202}$ found that the Panel erred in finding that allegations contained in the section III of the panel requests (including those concerning minimal price requirements) met the requirements of Article 6.2 of the Understanding on Rules and Procedures Governing the Settlement of Disputes. ${ }^{203}$ In the $A B$ view the complainants in their panel requests failed to 'provide sufficiently clear linkages between the broad range of obligations [referred to] and the 37 challenged measures. ${ }^{204}$ Consequently, on these procedural grounds the $\mathrm{AB}$ declared 'moot and of no legal effect' the earlier Panel's findings in relation to claims raised under section III of the panel requests. ${ }^{205}$ It is disappointing that the Appellate Body did not offer its view on the interpretation of Article XI:I GATT and its applicability to state-driven export cartels. While the AB stripped the

\footnotetext{
195 Ibid. para. 7.997.

${ }^{196}$ Ibid. para. 7.1002 .

${ }^{197}$ Ibid. para. 7.1006

${ }^{198}$ Ibid. para. 7.1074

${ }^{199}$ Ibid. paras 7.1081-7.1082.

${ }^{200}$ China- Measures Related to the Exportation of Various Raw Materials. Notification of an Appeal by China under Article 16.4 and Article 17 of the Understanding on Rules and Procedures Governing the Settlement of Disputes (DSU), and under Rule 20(1) of the Working Procedures for Appellate Review, WT/DS394/11, WT/DS395/11, WT/DS398/10 (Sept. 2 2011), available at http://www.worldtradelaw.net/na/ds39810\%28na\%29.pdf (visited 7 January 2012).

${ }^{202}$ WTO Appellate Body Report, China- Measures Related to the Exportation of Various Raw Materials (ChinaMeasures Related to the Exportation of Various Raw Materials), WT/DS394/AB/R, WT/DS395/AB/R, WT/DS398/AB/R, adopted 30 January 2012.

${ }^{203}$ WTO, The Legal Texts: the Results of the Uruguay Round of Multilateral Trade Negotiations (Cambridge: CUP, 1999) 354.

${ }^{204}$ Appellate Body Report, China- Measures Related to the Exportation of Various Raw Materials, above n. 202, para. 234.

${ }^{205}$ Ibid. para. 235.
} 
earlier Panel report from its legal effects, the reasoning offered by the panellists reinforces a view advocating a greater role to be played by the trade regime in addressing transnational anticompetitive arrangements.

The recent Chinese export cartel cases in general illustrate a clash of economic systems and legal frameworks. Within the broader trade context, as outlined by Fox and Davis, ${ }^{206}$ antidumping rules encouraged China to influence export prices, so as to avoid antidumping litigation (by increasing export prices China could avoid accusation of dumping). This is possible thanks to the Chinese economic system characterized by significant state involvement in the running of economy. The set prices are then challenged abroad under antitrust laws. Furthermore, as China-Measures Related to the Exportation of Various Raw Materials suggests, they can be also targeted in the trade framework. If such a route proves feasible in the future, it would bring new dynamics to the interface between the trade and competition, further narrowing down the existing gap allowing for export cartels, by recognizing prohibition of state-driven export cartels.

From an antitrust perspective these cases, ${ }^{207}$ involving state-owned enterprises and considerable state involvement, pose a challenge for antitrust regimes. The successful reliance on the state-related defences may encourage more state-licensed export cartels, not only from China. Chinese support of export cartels already caused concerns. For example, Connor considered it 'a disturbing trend ${ }^{208}$ while another commentator bluntly characterized any successful reliance by Chinese cartelists on foreign state compulsion defence as 'a declaration of war on the market system. ${ }^{209}$ The next question will be raised: can one sue a state for antitrust violation? Until now this issue has not been answered in the positive by the courts or the legislature. The US government itself seems unwilling to follow this path: all above cases where brought by private plaintiffs and, as it appears, there is no such action brought by the Department of Justice. The answer in the negative would create a gap in the antitrust system, implicitly granting an antitrust immunity to anticompetitive foreign state action. If courts do not allow reliance on the mentioned avoidance techniques, or if one could

\footnotetext{
${ }^{206}$ See above text accompanying notes $147-152$.

${ }^{207}$ For a broader analysis of the mentioned cases in light of the state-related defences see Laura Zimmerman, 'Sovereignty-Based Defenses in Antitrust Cases against Chinese Manufacturers: Making Room for Diplomacy', 36 Brooklyn Journal of International Law 337 (2010).

${ }^{208}$ Cited in Andrew Longstreth, 'U.S. Courts Confront China's Involvement in Price Fixing', Reuters Legal, 11 March 2011, available at http://www.reuters.com/article/2011/03/11/us-china-vitamincidUSTRE72A4XH20110311 (visited 7 January 2012). ${ }^{209}$ Ibid.
} 
sue directly a state for antitrust violation, enforcement of the judgment will be the next practical and controversial issue to address. The US for example would not cooperate in the enforcement of a judgment against a legally operating and duly registered export cartel.

Furthermore, it may be inferred from the China-Measures Related to the Exportation of Various Raw Materials trade dispute that by bringing the case against China within the WTO framework, the US seems to have opted for reliance on the multilateral system. The measures restricting imports or exports are prohibited within this framework. If creation or operation of an export cartel can be attributed to a state itself, the provisions of WTO agreements should be applicable as the Panel in this case suggested. ${ }^{210}$ This said, one should keep in mind that trade disputes exclude private parties, who do not have standing and cannot seek redress in the WTO dispute settlement framework. This has two consequences. First, any action against a foreign export cartel with state involvement would depend on the decision of the executive in the affected state, which most probably would take into consideration a broader spectrum of issues than just harm caused by cartel operations. Second, any issue would be settled among states and no damages would be available to private parties harmed. ${ }^{211}$ Moreover, the companies which benefited from export cartels operations would keep the extra profits they made as they would not be directly penalized, and, therefore, they would have a comparative advantage against companies in the same industry from other states.

If the line of reasoning offered by the panel in the recent trade dispute was to be adopted in future, an issue would arise whether private plaintiffs could bring, in a follow-up, a piggyback antitrust action in the US against a foreign state, benefiting from the body of evidence analyzed within the WTO dispute settlement framework. Treble damages provide sufficient incentive to ask this question. This leads again to the question of enforcement against state-own enterprises or a foreign state itself.

These cases show that the present regulatory regime in general and antitrust in particular are ill-equipped to address foreign-state involvement in export cartels either in China or in the US. This is particularly so, when the challenged state is a non-market

\footnotetext{
${ }^{210}$ See above text accompanying notes 70-76.

${ }^{211}$ For discussion on the rights of private parties in the WTO framework see Aaron Catbagan, 'Rights of Action for Private Non-state Actors in the WTO Dispute Settlement System', 37 Denver Journal of International Law \& Policy 279 (2009). More generally on the position of the private parties in international economic law, also within the trade disputes: Alan O. Sykes, 'Public versus Private Enforcement of International Economic Law: Standing and Remedy', 34 The Journal of Legal Studies 631 (2005).
} 
economy, like, but not only, China, with complicated internal decision-making structure, hampering the allocation of responsibility and consequently liability. Furthermore, the extralegal factors, in particular the political and security considerations may be of paramount importance in any attempted enforcement. In addition, it seems that the stance of the international trade regime is not clear. Taking into consideration developments in ChinaMeasures Related to the Exportation of Various Raw Materials, it seems likely that the trade regime proves capable of addressing export cartels with state involvement, but that may not be the optimal solution.

\section{Mind the US- Japanese Friction}

The Chinese cases raise somehow similar challenges to those posed by Japanese export cartels in 1970s. At that time Japanese exports were heavily cartelized: in 1977 there were eighty-six officially registered export cartels, accounting for 20-30 per cent of all exports. ${ }^{212}$ Japanese legislation not only exempted them from the scope of national competition laws, but the Japanese Ministry of International Trade and Industry could have either suggested creation of a cartel through non-binding administrative guidance, and when this proved insufficient, it had the capacity and intended to order creation of a cartel. ${ }^{213}$ In light of the Japanese domestic cases from that period, Matsushita concludes that the administrative guidance might have been regarded as an official act of the Japanese government. $^{214}$ The economists had divergent options as to the competitive impact of the Japanese export cartels. ${ }^{215}$ The growing concern among the US businesses with the Japanese unfair business practices in general led to intergovernmental negotiations between the US and Japan, ${ }^{216}$ various antidumping cases and trade disputes, ${ }^{217}$ and effectively to a review of

\footnotetext{
${ }^{212}$ Mitsuo Matsushita, 'Export Control and Export Cartels in Japan', 20 Harvard International Law Journal 103 (1979), at 113-14.

${ }^{213}$ Ibid, at $123-24$.

${ }^{214}$ Ibid, at 124.

${ }^{215}$ While investigation by Jacquemin, Nambu and Dewez explained Japanese export cartels in line with the theory of collusion, Dick found that only in one of twelve industries analyzed cartels led to higher prices, while in other cases they led to cost reduction and quality assurance. Compare Alexis Jacquemin, et al., 'A Dynamic Analysis of Export Cartels: The Japanese Case', 91 The Economic Journal 685 (1981); Andrew R. Dick, 'The Competitive Consequences of Japan's Export Cartel Associations', 6 Journal of Japanese and International Economies 275 (1992), at 291. This reminds that cartels may be seen as private regulatory regimes. See Imelda Maher, 'Competition Law and Transnational Private Regulatory Regimes: Marking the Cartel Boundary', 38 Journal of Law and Society 119 (2011).

${ }^{216}$ Within the framework of the Structural Impediments Initiative. See Joint Report of the US-Japan Working Group on the Structural Impediments Initiative (SII) (28 June 1990), available at http://tcc.export.gov/Trade_Agreements/All_Trade_Agreements/exp_005583.asp (visited 7 January 2012). ${ }^{217}$ Among them Panel Report, Japan - Trade in Semi-Conductors. See above text accompanying notes 70-71.
} 
Japanese competition law, with Japan committing itself not to use cartels as tools of the industrial policy. ${ }^{218}$

In the landmark antitrust case from this period Matsushita, ${ }^{219}$ which made its way to the Supreme Court, US TV manufactures alleged that the Japanese TV manufactures created a cartel, applying predatory pricing on the US market, so as to drive US competitors out of the market. It was a duly registered export cartel under Japanese law. To afford the predation, it cartelized the domestic market where it charged supra-competitive prices. This case raised the issue of the foreign sovereign compulsion defence, although the Supreme Court itself did not address it, after finding that the alleged conduct did not injure the plaintiffs. ${ }^{220}$ The Court of Appeals found the compulsion defence inapplicable, noting inter alia that defendants departed from the minimum price set by the Japanese authorities and that the domestic part of the cartel violated Japanese laws. The court also concluded that the Japanese regulatory scheme 'merely provided an umbrella' allowing for the domestic antitrust exemption. ${ }^{221}$ The Japanese government in its amicus brief to the Supreme Court supported Japanese companies informing that it has directed them to organize the cartel and that it put in place the regulatory regime concerning prices. ${ }^{222}$ This position was supported by the US government. ${ }^{223}$ As Ganjaei points out, ${ }^{224}$ the stance of the US government reflected the changes in its foreign policy and the agreements between the US and Japan according to which Japan adopted voluntary controls of car exports to the US, ${ }^{225}$ a measure which later was itself prohibited in the outcome of the Uruguay Round. ${ }^{226}$ The US- Japanese friction shows how the US was able, through its foreign and trade policies, to bilaterally address and influence foreign competition regime.

\footnotetext{
${ }^{218}$ Patricia Isela Hansen, 'Antitrust in the Global Market: Rethinking Reasonable Expectations', 72 Southern California Law Review 1601 (1999), at 1616-17; Matsushita, at 480.

${ }^{219}$ Matsushita Electric Industrial Co. v. Zenith Radio Corp. (Matsushita), 475 U.S. 574 (1986).

${ }^{220}$ For detailed analysis see Ali Ganjaei, 'Matsushita Electric Industrial Co., Ltd. v. Zenith Radio Corp.: The Death Knell for Predatory Price Fixing and the Avoidance of a Standard for the Foreign Sovereign Compulsion Defense', 15 Denver Journal of International Law \& Policy 395 (1986).

${ }^{221}$ In re Japanese Elec. Prods Antitrust Litig., 723 F.2d 238, 315 (3th Cir. 1983).

${ }^{222}$ Brief of the Government of Japan as Amicus Curiae in Support of the Petition for A Writ of Certiorari, Matsushita Electric Industrial Co. v. Zenith Radio Corp. (Matsushita), No. 83-2004 (U.S. Jul. 6, 1984).

${ }^{223}$ Brief for the United States as Amicus Curiae Supporting Affirmance, Matsushita Electric Industrial Co. $v$. Zenith Radio Corp. (Matsushita), No. 83-2004 (U.S. Jun. 17, 1985).

${ }^{224}$ Ganjaei, above n 220, at 408.

${ }^{225}$ For an in-depth analysis of the US-Japanese negotiations and the Japanese voluntary export restraints from the trade and competition perspective see Spencer Weber Waller, 'Redefining the Foreign Compulsion Defense in U.S. Antitrust Law: The Japanese Auto Restraints and Beyond', 14 Law and Policy in International Business 747 (1982).

${ }^{226}$ Under Article 11.1(b) of the Agreement on Safeguards. WTO, above n 69, at 275. Compare Immenga, above n 28 , at $140-42$.
} 


\section{Conclusion}

The creativity of the corporate world seems unlimited. There is no reason to believe that businesses around the world would refrain from taking advantage of the present regulatory system allowing for export cartels. The absence of empirical data should not lead to the conclusion that the issue is nonexistent. The unique treatment accorded to export cartels at the moment, as compared to other types of cartels, by their tolerance or encouragement, and the immunity from domestic antitrust laws, is not a beneficial policy in the long-run.

The recent case law illustrates the deficiencies of the present regulatory framework. The lack of an international mechanism addressing export cartels forces targeted states to rely on extraterritorial application of national competition laws. In general this unilateral route, from a practical perspective, requires expertise and resources, which are scarce in many jurisdictions. As the Indian ANSAC case shows, the lack of an explicit legal basis in national legislation providing for extraterritoriality may hinder such actions. It also underlines that when binding international mechanisms in competition law are lacking, the matter will be addressed through trade policy when important economic interests are at stake. It suggests that it is in the best interest of the less powerful states who are interested in legal resolution of controversies arising from transnational anticompetitive conduct and who lack trade muscle, to work towards international consensus in this area. At the same time, the South African case shows that when competition law is free to take its course unobstructed, extraterritoriality may lead to positive outcomes and may be a useful tool in the fight with export cartels. It is noteworthy that both cases concerned the same officially registered and publicly known export cartel, which was earlier challenged in a developed competition law regime. This seems to be the only case of this nature.

The Chinese/US cases, in general, point out that export cartels may come also from the global South. If this development becomes a larger phenomenon, it could, in principle, reframe the discussion on export cartels in terms of possible tradeoffs. Some economists suggested tying a general prohibition of export cartels in developed countries ${ }^{227}$ with market access concessions on behalf of and transfers from developing world as a form of reciprocation. ${ }^{228}$ Were export cartels to become more widespread in the global South, any such 'package deal' would require reconsideration. Moreover, the Chinese export cartel cases

\footnotetext{
${ }^{227}$ Compare the discussion in the framework of the WTO Working Group on the Interaction of Trade and Competition Policy, see above text accompanying notes 39-60.

${ }^{228}$ In this vein Hoekman and Mavroidis, above n 76, at 19, 21-22; Hoekman and Saggi, above n 65.
} 
show that government's involvement in transnational anticompetitive conduct, like export cartels, poses a challenge to antitrust regimes. If the bulwark of sovereignty proves to provide a shelter in such scenarios, then there is a risk that state-protected export cartels become more prevalent, undermining not only the competition laws, but also the rules of international trade, by according entities engaged in such anticompetitive conduct a comparative advantage. This perspective may in fact incentivize international community to look for a solution to the issue of both private and public, state(s)-driven, export cartels. While it is unlikely to reach a compromise prohibiting public export cartels dealing with natural resources,${ }^{229}$ this as such should not restrain us from placing them on the international agenda as well, looking for a mutually beneficial solution with an intention to tighten up the gaps in the current regulatory framework.

The limits of unilateralism when dealing with export cartels lead to a conclusion that an international solution is needed. Soft forms of cooperation ${ }^{230}$ until now did not provide an answer to the challenge of export cartels, with the broadest forum- ICN- focusing its efforts on different antitrust issues. ICN could look at export cartels, but taking into consideration the de facto inseparable trade context and the relevance of antidumping rules, the WTO seems the right forum. It has many advantages, one of them being its almost universal membership. A broad international competition agreement, an idea which received attention of many commentators, ${ }^{231}$ seems unlikely in the medium term. A different, more realistic, solution is available. Fox suggested a limited approach: the 'perfection' of the existing commitments in the WTO framework, ${ }^{232}$ which through further clarification and compromise could adequately address the issue of export cartels. Although the interface of trade and competition does not have a glamorous past, it should not matter. Pragmatic thinking suggests that is the most efficient way forward.

\footnotetext{
${ }^{229}$ Compare Bernard Hoekman and Will Martin, 'Reducing Distortions in International Commoditymarkets: An Agenda for Multilateral Cooperation' (World Bank Policy Research Working Paper No. 5928, 2012), 24-25, available at http://ssrn.com/paper=1979289 (visited 7 January 2012).

${ }^{230}$ See generally Imelda Maher, 'Competition Law in the International Domain: Networks as a New Form of Governance', 29 Journal of Law and Society 111 (2002); Fox, above n 86.

${ }^{231}$ See, for example, Gerber; Oliver Budzinski, The Governance of Global Competition: Competence Allocation in International Competition Policy (Cheltenham: Edward Elgar, 2008); D. Daniel Sokol, 'Monopolists Without Borders: The Institutional Challenge of International Antitrust in a Global Gilded Age', 4 Berkeley Business Law Journal 37 (2007); Philip Marsden, A Competition Policy for the WTO (London: Cameron May, 2003); Andrew T. Guzman, 'Antitrust and International Regulatory Federalism', 76 New York University Law Review $1142(2001)$.

${ }^{232}$ Fox, above n 86, at 274.
} 
In recent years competition laws were introduced in many jurisdictions and considerable effort was invested by the international community in competition advocacy and voluntary cooperation between competition authorities (best exemplified by the creation of the International Competition Network which now has more than 100 members), leading to more dialogue and understanding in this area of law. This led, for example, to international consensus on international private hard core cartels (but not export cartels) as harmful and actual cooperation in their pursuit across jurisdictions. Taking this into consideration, the time is perhaps ripe to come back to the discussion on export cartels and to revisit narrowfocused proposals in this regard which could be introduced within the WTO framework. The one suggested by Sweeney seems particularly appealing: an agreement taking into account in antitrust investigations not only domestic, but also foreign harm caused by such cartels; reinforced by a positive comity (a commitment to investigate a particular case at the request of a foreign jurisdiction). ${ }^{233}$ Such a regime could be adopted as a plurilateral agreement, preferably on the side and not within a major negotiation round, open to all interested jurisdictions and subject to the WTO dispute settlement mechanism. Taking into consideration that China, as the discussed cases present, is caught between a rock of antidumping and a hard place of antitrust actions, it may be interested in such a solution. The US, on the other hand, facing now Chinese export cartels with considerable state involvement may find it worthwhile to sit down and negotiate as well so as to avoid similar but greater problems in the future. The European Union, which already within the framework of the WTO Woking Group took the view that the issue of export cartels should be addressed, would surely join the talks. While developing countries were quite sceptical about competition issues on the trade agenda, the Indian experience with the US soda ash export cartel, discussed above, shows that they may now find it in their best interests to work towards an international solution to export cartels, especially if approached outside the major round of trade negotiations. ${ }^{234}$ In fact if the tipping point has not been reached yet, the recent developments allow hoping that it is not too far away and more thought should be now

\footnotetext{
${ }^{233}$ Compare Sweeney, above n 13, at 107-08.

${ }^{234}$ CUTS Centre for Competition, Investment \& Economic Regulation, a non-governmental organization involved in competition law and policy advocacy in developing countries and widely known for promoting their perspective has been, for a long time, calling for an action addressing export cartels. Compare Pradeep S. Mehta, et al., 'Multilateral Competition Framework: In Need of a Fresh Approach' (CUTS Centre for Competition, Investment \& Economic Regulation Discussion Paper 2005), available at http://www.cutsccier.org/pdf/Multilateral_Competition_Framework_In_Need_of_a_Fresh_Approach.pdf (visited 7 January 2012).
} 
invested into consideration of possible scenarios addressing export cartels, both private and public, reflecting the current challenges. ${ }^{235}$

${ }^{235}$ Noting this dynamic Jenny and Mehta recently urged the WTO 'to undertake a serious and dispassionate study of the effects and the appropriate legal regime to regulate export cartels'. See Frederic Jenny and Pradeep S. Mehta, 'Global Problems and Solutions', The Financial Express, 13 January 2012, available at http://www.financialexpress.com/news/global-problems-\&-solutions/899105 (visited 13 January 2012). 


\section{Bibliography (selected)}

Aaron Ansel, 'Market Orientalism: Reassessing an Outdated Anti-Dumping Policy Towards the People's Republic of China', 35(3) Brooklyn Journal of International Law 883 (2010).

Florian Becker, 'The Case of Export Cartel Exemptions: Between Competition and Protectionism', 3(1) Journal of Competition Law and Economics 97 (2007).

Aditya Bhattacharjea, 'Export Cartels-A Developing Country Perspective', 38(2) Journal of World Trade 331 (2004).

Aditya Bhattacharjea, 'Predation, Protection and the 'Public Interest", 35(49) Economic and Political Weekly 4327 (2000).

Aditya Bhattacharjea, 'The Case for a Multilateral Agreement on Competition Policy: A Developing Country Perspective', 9(2) Journal of International Economic Law 293 (2006).

Gary B. Born, International Civil Litigation in United States Courts: Commentary \& Materials, 3rd ed. (The Hague: Kluwer Law International, 1996).

Oliver Budzinski, The Governance of Global Competition: Competence Allocation in International Competition Policy (Cheltenham: Edward Elgar, 2008).

Aaron Catbagan, 'Rights of Action for Private Non-state Actors in the WTO Dispute Settlement System', 37(2) Denver Journal of International Law \& Policy 279 (2009).

Shohit Chaudhry and Kartinkey Mahajan, 'The Case for an Effective Extraterritorial Jurisdiction of Competition Commission of India in Light of International Practices', 32(6) European Competition Law Review 314 (2011).

John M. Connor, Global Price Fixing, 2nd ed. (Heidelberg: Springer, 2008).

Maher M. Dabbah, 'Competition Law and Policy in Developing Countries: A Critical Assessment of the Challenges to Establishing an Effective Competition Law Regime', 33(3) World Competition 457 (2010).

Joel Davidow and Hal Shapiro, 'The Feasibility and Worth of a World Trade Organization Competition Agreement', 37(1) Journal of World Trade 49 (2003).

Reza Dibadj, 'Conscious Parallelism Revisited', 47(3) San Diego Law Review 589 (2010).

Andrew R. Dick, 'Are Export Cartels Efficiency-Enhancing or Monopoly-Promoting' (University of California, Department of Economics Working Paper No. 601, 1990).

Andrew R. Dick, 'The Competitive Consequences of Japan's Export Cartel Associations', 6(3) Journal of Japanese and International Economies 275 (1992).

Josef Drexl, 'International Competition Policy after Cancun', 27(3) World Competition 419 (2006).

Claus-Dieter Ehlermann and Lothar Ehring, 'WTO Dispute Settlement and Competition Law: Views from the Perspective of the Appellate Body's Experience', 26 Fordham International Law Journal 1505 (2003).

Simon J. Evenett, et al., 'International Cartel Enforcement: Lessons from the 1990s', 24 World Economy 1221 (2001).

Simon J. Evenett, 'Five Hypotheses Concerning the Fate of the Singapore Issues in the Doha Round', 23(3) Oxford Review of Economic Policy 392 (2007). 
Harry First, 'Vitamins Case: Cartel Prosecutions and the Coming of International Competition Law', 68 Antitrust Law Journal 711 (2001).

Eleanor M. Fox and Dennis Davis, 'Industrial Policy And Competition- Developing Countries As Victims And Users', Fordham Corporate Law Institute 151 (2006).

Eleanor M. Fox and Janusz A. Ordover, 'The Harmonization of Competition and Trade Law: the Case for Modest Linkages of Law and Limits to Parochial State Action', 19 World Competition 5 (1995).

Eleanor M. Fox, 'Antitrust without Borders. From Roots to Codes to Networks' in Andrew T. Guzman (ed), Cooperation, Comity, and Competition Policy (Oxford: OUP, 2011).

Eleanor M. Fox, 'Can we Solve the Antitrust Problems of Globalization by Extraterritoriality and Cooperation? Sufficiency and Legitimacy', 48(2) Antitrust Bulletin 355 (2003).

Eleanor M. Fox, 'Competition Law and the Millennium Round', 2(4) Journal of International Economic Law 665 (1999).

Eleanor M. Fox, 'Economic Development, Poverty, and Antitrust: The Other Path', 13 Southwestern Journal of Law and Trade in the Americas 211 (2007).

Eleanor M. Fox, 'International Antitrust and the Doha Dome ', 43 Virginia Journal of International Law 911 (2003).

Wilbur L. Fugate, 'The Export Trade Exception to the Antitrust Laws: The Old Webb-Pomerene Act and the New Export Trading Company Act', 15 Vanderbilt Journal of Transnational Law 673 (1982).

Michal S. Gal, 'Extraterritorial Application of Antitrust- The Case of a Small Economy: Israel' in Andrew T. Guzman (ed), Cooperation, Comity, and Competition Policy (Oxford: OUP, 2011).

Michal S. Gal, 'Free Movement of Judgments: Increasing Deterrence of International Cartels Though Jurisdictional Reliance' (New York University School of Law Law \& Economics Research Paper Series No. 08-44, 2008), available at http://ssrn.com/paper=1291844.

Michal S. Gal, 'The Effects of Smallness and Remoteness on Competition Law - The Case of New Zealand', 14(2) Competition \& Consumer Law Journal 292 (2007).

Damien Geradin, et al., 'Extraterritoriality, Comity and Cooperation in EC Competition Law' in Andrew T. Guzman (ed), Cooperation, Comity, and Competition Policy (Oxford: OUP, 2011).

Damien Geradin, et al., 'Extraterritoriality, Comity and Cooperation in EC Competition Law' (SSRN eLibrary 2008), available at http://ssrn.com/abstract=1175003.

David J. Gerber, Global Competition: Law, Markets, and Globalization (Oxford OUP, 2010).

Walter van Gerven, 'EC Jurisdiction in Antitrust Matters: The Wood Pulp Judgment', Fordham Corporate Law Institute 451 (1989).

Andrew T. Guzman, 'Antitrust and International Regulatory Federalism', 76(4) New York University Law Review 1142 (2001).

Christopher Harding and Julian Joshua, Regulating Cartels in Europe, 2nd ed. (Oxford: OUP, 2010).

Trudi Hartzenberg, 'Competition Policy and Practice in South Africa: Promoting Competition for Development', 26(3) Northwestern Journal of International Law \& Business 667 (2006).

Barry E. Hawk, 'International Antitrust Policy and the 1982 Acts: The Continuing Need for Reassessment', 51 Fordham Law Review 201 (1982). 
Bernard Hoekman and Kamal Saggi, 'Tariff Bindings and Bilateral Cooperation on Export Cartels', 83(1) Journal of Development Economics 141 (2007).

Bernard Hoekman and Petros C. Mavroidis, 'Economic Development, Competition Policy and the World Trade Organization', 37(1) Journal of World Trade 1 (2003).

Bernard Hoekman and Will Martin, 'Reducing Distortions in International Commodity Markets: An Agenda for Multilateral Cooperation' (World Bank Policy Research Working Paper No. 5928, 2012), available at http://ssrn.com/paper=1979289.

Bernard Hoekman, 'Operationalizing the Concept of Policy Space in the WTO: Beyond Special and Differential Treatment', 8(2) Journal of International Economic Law 405 (2005).

Hugh M. Hollman and William E. Kovacic, 'The International Competition Network: Its Past, Current and Future Role', 20(2) Minnesota Journal of International Law 274 (2011).

Ulrich Immenga, 'Export Cartels and Voluntary Export Restraints between Trade and Competition Policy', 4(1) Pacific Rim Law \& Policy Journal 93 (1995).

Alexis Jacquemin, et al., 'A Dynamic Analysis of Export Cartels: The Japanese Case', 91(363) Economic Journal 685 (1981).

Merit E. Janow, 'What Role for Competition Policy in the WTO?' (2002), available at http://www.columbia.edu/ mj60/PDF/janow\%20rorcam\%20912.pdf.

Frederic Jenny and Pradeep S. Mehta, 'Global Problems and Solutions', The Financial Express, 13 January 2012, available at http://www.financialexpress.com/news/global-problems-\&-solutions/899105.

Frederic Jenny, 'Cartels and Collusion in Developing Countries Lessons from Empirical Evidence', 29(1) World Competition 109 (2006).

Dieter G. F. Lange and John Byron Sandage, 'The Wood Pulp Decision and its Implications for the Scope of EC Competition Law', 26 Common Market Law Review 137 (1989).

David A. Larson, 'An Economic Analysis of the Webb-Pomerene Act', 13(2) Journal of Law and Economics 461 (1970).

Margaret C. Levenstein and Valerie Y. Suslow, 'Changing International Status of Export Cartel Exemptions', 20 American University International Law Review 785 (2005).

Margaret C. Levenstein and Valerie Y. Suslow, 'Contemporary International Cartels and Developing Countries: Economic Effects and Implications for Competition Policy', 71 Antitrust Law Journal 801 (2004).

Imelda Maher, 'Competition Law and Transnational Private Regulatory Regimes: Marking the Cartel Boundary', 38(1) Journal of Law and Society 119 (2011).

Imelda Maher, 'Competition Law in the International Domain: Networks as a New Form of Governance', 29(1) Journal of Law and Society 111 (2002).

Imelda Maher, 'Networking Competition Authorities in the European Union: Diversity and Change' in ClausDieter Ehlermann and Isabela Atanasiu (eds), European Competition Law Annual 2002: Constructing The EU Network Of Competition Authorities (Oxford: Hart Publishing, 2004).

Philip Marsden, A Competition Policy for the WTO (London: Cameron May, 2003).

Marek Martyniszyn, 'A Comparative Look on Foreign State Compulsion as a Defence in Antitrust Litigation', 8(2) Competition Law Review 143 (2012), available at http://ssrn.com/abstract=1986032. 
Marek Martyniszyn, 'Avoidance Techniques: State Related Defences in International Antitrust Cases' (CCP Working Paper No. 11-2, 2011), available at http://ssrn.com/abstract=1782888.

Mitsuo Matsushita, 'Basic Principles of the WTO and the Role of Competition Policy', 3 Washington University Global Studies Law Review 363 (2004).

Mitsuo Matsushita, 'Export Control and Export Cartels in Japan', 20(1) Harvard International Law Journal 103 (1979).

Mitsuo Matsushita, 'The Intersection of Industrial Policy and Competition: The Japanese Experience', 72 Chicago-Kent Law Review 477 (1996).

Kasturi Moodaliyar and Keith Weeks, 'Characterising Price Fixing: A Journey Through the Looking Glass with ANSAC', 11(3) South African Journal of Economic and Management Sciences 337 (2008).

Jackie Mortensen, 'Extending the Extraterritorial Reach of the Trade Practices Act', 614 Australian Trade Practices News 1 (2009).

Chris Noonan, The Emerging Principles of International Competition Law (Oxford: OUP, 2008).

Anestis S. Papadopoulos, The International Dimension of EU Competition Law and Policy (Cambridge: CUP, 2010).

James E. Rauch, 'Networks Versus Markets in International Trade', 48 Journal of International Economics 7 (1999).

Christian Schultz, 'Export Cartels and Domestic Markets', 2(3) Journal of Industry, Competition and Trade 233 (2002).

Loius B. Schwartz, 'American Antitrust and Trading with State-Controlled Economies', 25 Antitrust Bulletin 513 (1980).

D. Daniel Sokol, 'International Antitrust Institutions' in Andrew T. Guzman (ed), Cooperation, Comity, and Competition Policy (Oxford: OUP, 2011).

D. Daniel Sokol, 'Monopolists Without Borders: The Institutional Challenge of International Antitrust in a Global Gilded Age', 4(1) Berkeley Business Law Journal 37 (2007).

D. Daniel Sokol, 'Order without (Enforceable) Law: Why Countries Enter into Non-Enforceable Competition Policy Chapters in Free Trade Agreements', 83(1) Chicago-Kent Law Review 231 (2008).

D. Daniel Sokol, 'What do We Really Know About Export Cartels and What is the Appropriate Solution?', 4(4) Journal of Competition Law and Economics 967 (2008).

George J. Stigler, 'A Theory of Oligopoly', 72(1) Journal of Political Economy 44 (1964).

Brendan Sweeney, 'Combating Foreign Anti-competitive Conduct: What Role for Extraterritorialism?', 8(1) Melbourne Journal of International Law 35 (2007).

Brendan Sweeney, 'Export Cartels: Is there a Need for Global Rules?', 10(1) Journal of International Economic Law 87 (2007).

Brendan Sweeney, The Internationalisation of Competition Rules (London: Routledge, 2010).

Alan O.Sykes, 'Public versus Private Enforcement of International Economic Law: Standing and Remedy', 34(2) Journal of Legal Studies 631 (2005).

Spencer Weber Waller, Antitrust and American Business Abroad, 3rd ed. (St. Paul Minn.: West Group, 19972010). 
Spencer Weber Waller, et al., Special Defenses in International Antitrust Litigation (Chicago: ABA Antitrust Section, 1995).

Spencer Weber Waller, 'Redefining the Foreign Compulsion Defense in U.S. Antitrust Law: The Japanese Auto Restraints and Beyond', 14 Law and Policy in International Business 747 (1982).

Spencer Weber Waller, 'The Failure of the Export Trading Company Program', 17(2) North Carolina Journal of International Law and Commercial Regulation 239 (1992).

James D. Whitney, 'The Causes and Consequences of Webb-Pomerene Associations: A Reappraisal', 38 Antitrust Bulletin 395 (1993).

Bruno Zanettin, Cooperation Between Antitrust Agencies at the International Level (Oxford: Hart Publishing, 2002).

Ka Zeng and Wei Liang, 'US Antidumping Actions Against China: the Impact of China's Entry into the World Trade Organization', 17(3) Review of International Political Economy 562 (2010).

Laura Zimmerman, 'Sovereignty-Based Defenses in Antitrust Cases against Chinese Manufacturers: Making Room for Diplomacy', 36(1) Brooklyn Journal of International Law 337 (2010). 